ANA MARIA FrAgA

\title{
ESTUDO DE FUNÇÃO DE HIPK2 DURANTE O DESENVOLVIMENTO EMBRIONÁRIO
}

Dissertação apresentada ao Instituto de Biociências da Universidade de São Paulo, para a obtenção do Título de Mestre em Ciências, na área de Biologia/Genética.

Orientadora: Profa. Dra. Lygia da Veiga Pereira Carramaschi

SÃO PAULO

2007 

Fraga, Ana Maria

Estudo de função de Hipk2 durante o desenvolvimento embrionário /

Ana Maria Fraga. - São Paulo, 2007.

Dissertação (Mestrado) - Instituto de Biociências da Universidade de São Paulo. Departamento de Genética e Biologia Evolutiva.

Área de concentração: Biologia/Genética.

Orientadora: Lygia da Veiga Pereira Carramaschi.

Descritores: 1. HIPK2. 2. DESENVOLVIMENTO. 3. RNAi. 4. EXPRESSÃO GÊNICA.

\section{Comissão Julgadora}

Prof(a) Dr(a)

Prof(a) Dr(a)

$\operatorname{Prof}(a) \operatorname{Dr}(a)$

Prof(a) Dr(a)

Profa. Dra. Orientadora 
À minha família, meu porto seguro. 
À minha orientadora, Profa. Dra. Lygia da Veiga Pereira Carramaschi, por estar sempre pronta a ajudar, pelos conselhos sempre pertinentes e pelo ânimo nos momentos complicados.

Aos meus pais, por me garantirem que era possível. Ao meu pai, pelo "não esquenta a cuca...”, procurei fazer disso meu mantra, não sei se consegui. À minha mãe, por saber exatamente qual era o problema sem eu precisar dizer.

Às minhas irmãs, por estarem comigo sempre, por ouvirem minhas reclamações, por tentarem me alegrar (tarefa árdua nas horas de "urubu") nos momentos tristes, e me acompanharem na “alienação necessária”. Sem vocês, eu não conseguiria.

Ao Prof. Dr. José Xavier-Neto, meu co-orientador “extra-oficial”, pela enorme ajuda durante o tempo em que trabalhei sob sua supervisão, pelo aprendizado diário e pelas frutíferas discussões científicas.

À CAPES e USP pelo apoio financeiro durante o mestrado.

Aos meus amigos de laboratório, de agora e de antes, Bruno, Christian, Clarisse, Cynthia, Débora, Denilce, Enrico, Gaëlle, Gustavo, Joana, Karla, Lys, Mariana, Raquel, Roberto, por todas as alegrias e tristezas compartilhadas. Em especial à Joana e Raquel, pela revisão, pelos conselhos e pela amizade. 
Aos amigos que já passaram ou trabalham no laboratório de Genética e Cardiologia Molecular do Incor-USP, Allysson, Ana Paula, Camila, Hozana, Marcos, Marilene, Michelle, Priscila, Roberta, Rodrigo, Tatiana, Vânia. Foi ótimo trabalhar com vocês! Em especial à Ana pelo excelente trabalho no Corel, ao Allysson pela revisão, à Roberta, Hozana e Priscila pelos conselhos sobre as imagens.

Aos laboratórios coordenados pelos Drs. Ângela Morgante, Eduardo Gorab, Luis Eduardo Soares Netto, Maria Rita Santos Passos Bueno, Mayana Zatz e Regina Célia Mingroni Netto, pelos equipamentos emprestados e ajuda científica.

Aos amigos dos laboratórios das Profas. Dras. Ângela Morgante, Luciana Haddad e Regina Célia, em especial à Fátima, Fernando, Jacaré, Juliana, Larissa, Ligia, Lílian, Mara e Rafaella, pela ajuda e amizade neste tempo de iniciação e mestrado.

À Profa. Dra. Luciana Vasques, pela imensa colaboração e amizade.

À Profa. Dra. Silvia Massironi e sua equipe, por disponibilizar os camundongos para os experimentos e pela ajuda nunca negada.

À Dra. Marina Soukoian, pela ajuda incondicional e pela amizade que supera a distância.

Às secretárias do Depto. de Genética e Biologia Evolutiva, Deisy e Helenice, minhas “coorientadoras”. 
À Profa. Dra. Sabine Eggers, pela amizade desenvolvida no tempo das monitorias de Genética Humana.

Aos Coiros da Silva, as primeiras pessoas em que penso na hora do desespero, sempre dispostos a mimar esta peregrina que sofre com a tecnologia... À Fernanda, Bruno e Danilo, meus irmãos também.

Aos amigos de turma da Bio, José, Marisa, Melissa, Tiago. A gente fica sem se ver um tempão, mas quando se encontra é sempre uma festa!

À Leila e Quéren, minhas amigas-irmãs, pela amizade que perdura o tempo. 


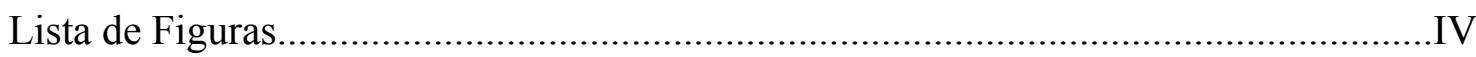

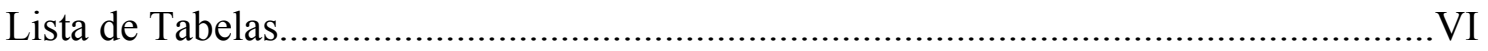

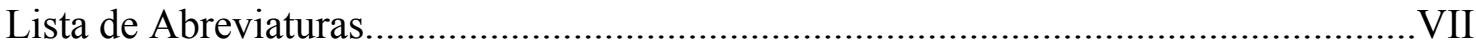

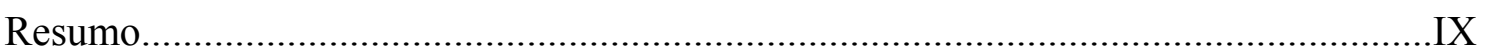

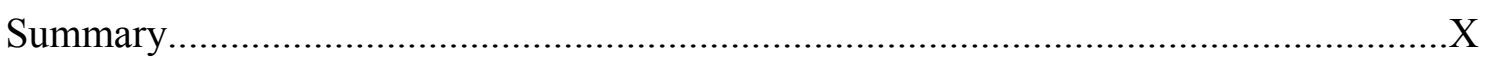

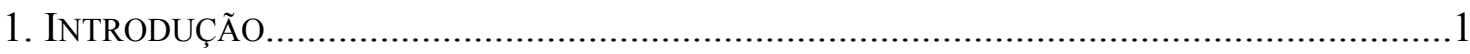

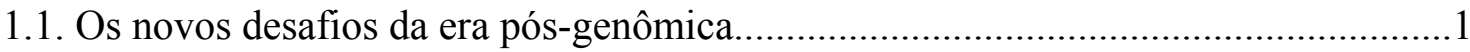

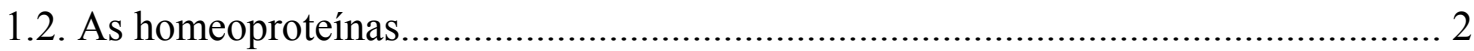

1.3. Regulação de homeoproteínas - as HIPKs........................................................

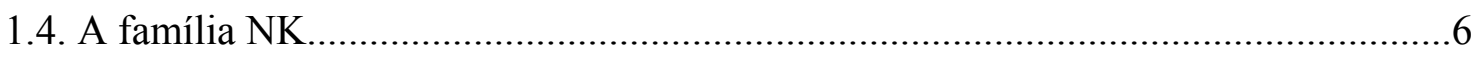

1.5. Estudos de função de Hipk2 durante o desenvolvimento embrionário......................7

1.6. Atuação de HIPK2 em outras vias........................................................................

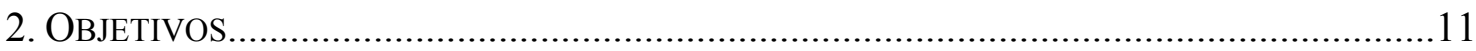

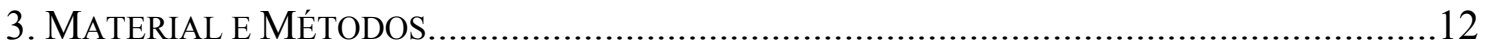

3.1. Estudo da expressão de Hipk2 durante o desenvolvimento......................................12

3.1.1. Escolha e obtenção da sonda de RNA (ribossonda) para hibridação in situ.

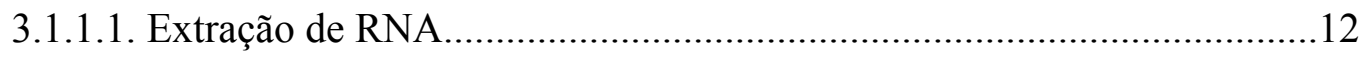

3.1.1.2. Reverse Transcriptase - PCR (RT-PCR)..............................................13

3.1.1.3. Clonagem dos fragmentos em pGEM...............................................14 
3.1.1.4. Transformação da ligação em bactérias.

3.1.1.5. Preparação do plasmídeo em pequena escala (miniprep)........................14

3.1.1.6. Digestão com enzimas de restrição.......................................................15

3.1.1.7. Clonagem em pBluescript .......................................................... 15

3.1.1.8. Seqüenciamento de plasmídeos.......................................................16

3.1.1.9. Preparação de plasmídeo em média escala (midiprep) e purificação do plasmídeo .16

3.1.1.10. Transcrição in vitro - síntese da ribossonda.........................................17

3.1.2. Obtenção de embriões de camundongos.......................................................18

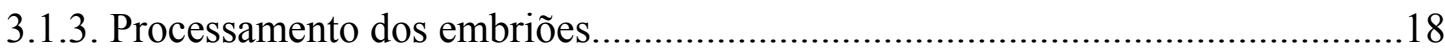

3.1.4. Hibridação in situ em cortes de embriões......................................................18

3.2. Efeito do silenciamento (knockdown) de HIPK2 por shRNA (short hairpin RNA)

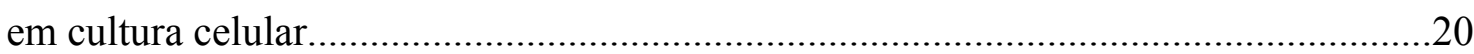

3.2.1. Desenhos dos oligonucleotídeos e clonagem em $p$ Super................................20

3.2.2. Preparação de plasmídeo em larga escala (Maxiprep)......................................22

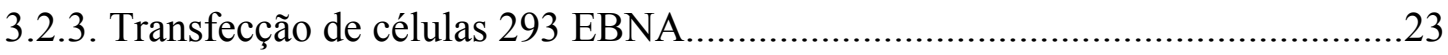

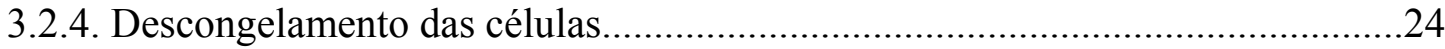

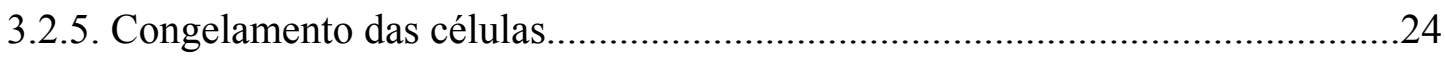

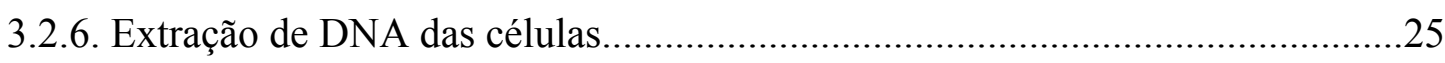

3.2.7. Verificação de clones celulares positivos........................................................25

3.2.8. Análise da expressão gênica nas células transfectadas.....................................26

3.2.8.1. RT- PCR em tempo real (Real Time-PCR)........................................26

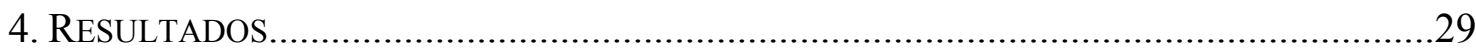

4.1. Perfil de expressão de Hipk2 durante o desenvolvimento embrionário...................29 
4.1.1. Síntese da ribossonda para as reações de hibridação in situ. .29

4.1.2. Hibridação in situ em cortes histológicos de embriões de camundongos...........30

4.2. Regulação por HIPK2 da expressão de genes homeobox e HIPKs.........................39

4.2.1. Construção dos vetores para silenciamento de $H I P K 2$.....................................39

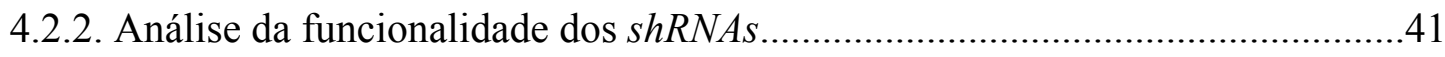

4.2.3. Efeito da inativação de HIPK2 na expressão de genes homeobox e HIPKs.......46

5. DiSCUSSÃO.

5.1. Perfil de expressão de Hipk2 durante o desenvolvimento embrionário de camundongos.

5.2. Regulação de expressão gênica por HIPK2. .53

5.2.1. Regulação de expressão de HIPK1 e HIPK3 por HIPK2 ....................................54

5.2.2. Controle da expressão de genes homeobox por HIPK2 2.....................................56

6. CONCLUSÃO. .60

7. REFERÊNCIAS BIBLIOGRÁFICAS 62 
Figura 1. Vista esquemática do complexo homeodomínio-DNA.....................................3

Figura 2. Diagrama esquemático das proteínas HIPK1, HIPK2 e HIPK3 .......................5

Figura 3. Ativação de p53 em resposta a danos ao DNA................................................10

Figura 4: Diagrama esquemático da seqüência de cDNA de Hipk2 murina e a localização das regiões selecionadas para ribossondas nas hibridações in situ. .30

Figura 5: Expressão de Hipk2 em embrião de 9.5 dpc.................................................31

Figura 6: Expressão de Hipk2 em cortes sagitais de embriões de 11.5 $\mathrm{dpc}$ .32

Figura 7: Expressão de Hipk2 em embriões de 12.5 dpc 33

Figura 8: Expressão de Hipk2 em embriões de 13.5 dpc

Figura 9: Perfil de expressão de Hipk2 em embriões de 14.5 dpc

Figura 10: Expressão de Hipk2 por hibridação in situ em cortes parassagitais de embriões de 15.5 dpc. .36

Figura 11: Expressão de Hipk2 em embriões de 17.5 dpc

Figura 12: Características das seqüências-alvo e sua localização no transcrito de HIPK2 $39-40$

Figura 13: PCR para confirmação da presença do vetor pSuper nas células transfectadas. .41

Figura 14: Expressão de HIPK2 em clones transfectados com vetores para silenciamento do gene por RT-PCR semi-quantitativa 42

Figura 15: Quantificação da expressão de $H I P K 2$ em clones transfectados com vetores para silenciamento do gene por RT-PCR em tempo real. 
Figura 16: Expressão de $H I P K 2$ em clones transfectados com vetores para silenciamento do gene por RT-PCR em tempo real, em relação a diferentes controles endógenos .44

Figura 17: Análise por RT-PCR em tempo real da expressão de HIPK2 em diferentes clones transfectados com pS4.

Figura 18: Efeito do silenciamento de HIPK2 nos níveis de expressão dos genes HIPKs. .47

Figura 19: Efeito do silenciamento de HIPK2 nos níveis de expressão de genes homeobox. .48

Figura 20: Representação esquemática da expressão de Hipk2 durante o desenvolvimento embrionário de camundongos. .50 
Tabela 1: Iniciadores utilizados na obtenção de ribossondas para hibridação in situ.....13 Tabela 2: Oligonucleotídeos desenhados e sintetizados a partir da seqüência de HIPK2 para expressão de shRNA

Tabela 3: Iniciadores utilizados nas reações de PCR em tempo real (Real Time-PCR)..27

Tabela 4: Expressão de Hipk2 ao longo do desenvolvimento embrionário de camundongos. 38 
cDNA - DNA complementar

dpc - dias pós-coito

EST - do inglês Expressed Sequence Tag

FISH - do inglês Fluorescent in situ hybridization

GAPDH - gene da gliceraldeído 3-fosfato desidrogenase

HID - do inglês Homeoproteins Interaction Domain

HIPK - Homeodomain-Interating Protein Kinase

HPRT1 - gene da hipoxantina ribosiltransferase 1

$H M B S$ - gene da hidroximetilbilano sintase

$\mathrm{Kb}-$ kilobases

nt - nucleotídeos

ORESTES - do inglês Open Reading Frame EST Sequences

$\mathrm{pb}$ - pares de base

PCR - reação em cadeia de polimerase

PEST - domínio rico em prolina (P), ácido glutâmico (E), serina (S) e treonina (T)

RanBPM - do inglês $R A N$ binding protein $M$

RI - radiação ionizante

RNAi - RNA de interferência

RT-PCR - reação em cadeia da polimerase após transcrição reversa

shRNA - do inglês short hairpin-RNA

siRNA - do inglês small interfering $R N A$

TA - temperatura ambiente

TGF $\beta$ - do inglês transforming growth factor $\beta$ 
TRADD - do inglês TNF-R1 associated death domain

UTR - do inglês untranslated region

UV - radiação ultravioleta

$\mathrm{YH}$ - domínio rico em histidina $(\mathrm{Y})$ e tirosina $(\mathrm{H})$ 
HIPK2 (homeodomain interacting protein kinase 2) é uma proteína quinase nuclear, originalmente identificada por interagir com homeoproteínas. Sua atividade quinase contribui para a regulação de diversas vias, ativando o programa de morte celular em resposta a estímulos externos ou promovendo diferenciação celular por atuar como co-fator de homeoproteínas. A extensa similaridade estrutural com as outras proteínas da mesma família, HIPK1 e HIPK3, sugere que as três HIPKs possuem funções redundantes.

Este trabalho pretendeu contribuir para a elucidação das funções de Hipk2 avaliando a expressão desta durante o desenvolvimento em camundongo. Observou-se ampla distribuição do transcrito desde o dia 9.5 pós-coito (dpc). Com o progresso do desenvolvimento, a expressão passou a se concentrar principalmente em tecidos nervosos, sugerindo uma participação de Hipk2 na morfogênese destes.

Além disso, foi desenvolvido um sistema in vitro para se avaliar as funções de HIPK2 humana. A inibição de HIPK2 por RNAi em cultura celular humana levou ao aumento de expressão de genes $H I P K s$, indicando que possa haver um mecanismo de controle transcricional que ajuste os níveis de proteínas HIPKs na célula. O silenciamento de HIPK2 também provocou aumento de expressão de alguns genes homeobox avaliados, sugerindo que HIPK2 possa reprimir a expressão destes genes em humanos. A análise global de expressão gênica e proteômica nas células deficientes para $H I P K 2$ poderá indicar as diferentes vias de atuação desta proteína. 
HIPK2 is a nuclear protein kinase, originally identified because of its interaction with homeoproteins. Its kinase activity can regulate several pathways, triggering the apoptotic program in response to external stimuli or promoting differentiation by acting as a cofactor for homeoproteins. The extensive similarity with the other two proteins from the same family, HIPK1 and HIPK3, suggests that HIPKs have redundant functions.

This work tried to contribute to the body of knowledge regarding the functions of Hipk2 addressing its expression during the mouse development. The transcript is broadly expressed in mouse embryos from day 9.5 post-coitum. As development progresses, its expression concentrates mainly in neural tissues, suggesting a role of Hipk2 in its morphogenesis.

In addition, an in vitro system was developed to study HIPK2 functions in human cells. The HIPK2 silencing by RNAi in human cell culture led to a raise in expression of the other HIPKs genes, indicating that there might be a transcriptional mechanism controlling HIPKs proteins levels in the cell. HIPK2 inhibition also caused an increase in expression of some homeobox genes, suggesting that HIPK2 can negatively regulate their expression in humans. A global approach of gene expression and proteomics analysis in the HIPK2 deficient cells will help to identify different pathways in which HIPK2 participates. 


\section{INTRODUÇÃO}

\subsection{Os novos desafios da era pós-genômica}

Com a publicação da primeira versão da seqüência do genoma humano no início de 2001 (LANDER et al., 2001; VENTER et al., 2001), o desafio que se seguiu foi o de identificar genes, suas regiões regulatórias e perfis de expressão em diferentes tecidos. Mais ainda, tornou-se imprescindível relacioná-los a funções celulares e avaliar o impacto de polimorfismos e mutações em investigação clínica.

Estudos complementares aos do seqüenciamento do genoma humano foram realizados, como o do projeto Genoma Humano do Câncer desenvolvido no Instituto Ludwig de Pesquisa sobre o Câncer. O objetivo deste projeto foi determinar seqüências parciais de genes expressos principalmente em neoplasias utilizando uma nova metodologia, patenteada pelo Instituto Ludwig, conhecida como ORESTES (do inglês Open Reading Frame EST Sequences - DiAs NeTO et al., 2000; CAMARGO et al., 2001). A técnica permite seqüenciar a região central dos cDNAs, o que complementa dados obtidos a partir de métodos tradicionais de seqüenciamento, que exploram apenas as extremidades das seqüências (DiAs NETO et al., 2000).

A partir de dados do projeto Genoma Humano do Câncer, foi identificada uma nova EST humana (do inglês Expressed Sequence Tag, "etiqueta" de seqüência expressa) que apresentava $89 \%$ de identidade com a seqüência codificadora da proteína Hipk2 (Homeodomain-Interacting Protein Kinase 2), descrita em camundongos por Kim e colaboradores (1998). Estes autores pretendiam identificar parceiros de interação de homeoproteínas. Usando como isca uma homeoproteína da família NK em ensaios de duplo-híbrido, foram identificadas três proteínas muito semelhantes, agrupadas numa classe denominada HIPK. 
Para melhor compreensão do trabalho que se desenvolveu, é necessário fazer um breve histórico sobre as homeoproteínas, suas funções e as conseqüências da associação das HIPKs a elas.

\subsection{As homeoproteínas}

As homeoproteínas são fatores de transcrição de fundamental importância durante o desenvolvimento embrionário, que possuem um domínio muito conservado entre eles, de 60-61 aminoácidos (homeodomínio - QIAN et al., 1989), sugerindo uma provável relação funcional e evolutiva entre os vários membros da família (revisto por Duboule, 1992). Essa região corresponde à parte da proteína que reconhece seqüências específicas de DNA. O homeodomínio é codificado por uma seqüência de 180-183 nucleotídeos denominada homeobox e, por esta razão, os genes que possuem essa seqüência são chamados genes homeobox (MCGINNIS et al., 1984; SCOTT \& WEINER, 1984).

A análise da estrutura tridimensional do homeodomínio revelou que ele é composto de três $\alpha$-hélices, sendo que a segunda e a terceira hélices se organizam no motivo hélicevolta-hélice, comum a várias proteínas regulatórias de procariotos (BRENNAN \& MATTHEWS, 1989). A hélice 3 é a que efetivamente reconhece e faz contato com o DNA de seqüência específica (revisto por BILLETER, 1996; Fig.1). 


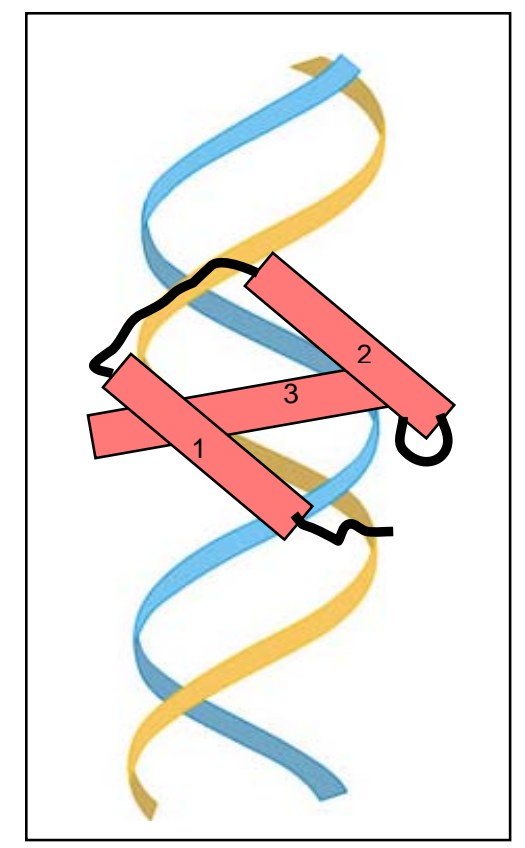

Figura 1. Vista esquemática do complexo homeodomínio-DNA. A dupla-fita de DNA é representada em azul e amarelo. Os retângulos em rosa representam as hélices 1, 2 e 3 do homeodomínio. A hélice 3 é a que reconhece a seqüência de DNA. Adaptado de Billeter, 1996.

O primeiro relato sobre homeoproteínas foi feito por Bateson em 1894. Trabalhando com drosófilas, esse autor descreveu mutações que provocavam alterações dramáticas de fenótipo. O termo homeo significa "similar", e Bateson denominou de homeóticas aquelas mutações em que estruturas características de determinados segmentos estavam presentes em outras regiões do corpo. É o caso da mutação Antennapedia, em que um par de pernas substitui um par de antenas na cabeça das moscas (revisto por GEHRING, 1987).

Hoje sabemos que as alterações de fenótipo descritas por Bateson são causadas por mutações ou mudanças no padrão de expressão de um grupo de genes homeobox, os chamados genes homeóticos. Estudos genéticos de Lewis (1978) e Kaufman e 
colaboradores (1980) indicaram que esses genes se encontravam agrupados (em cluster) no cromossomo 3 (complexo homeótico ou HOM-C) de drosófila.

Proteínas que apresentam homeodomínio foram descritas em todos os metazoários, além de fungos e plantas, indicando sua origem remota no curso na evolução dos eucariotos (KAPPEN et al., 1993). Vale ressaltar ainda que muitos genes possuem o homeobox, mas nem todos são homeóticos, ou seja, nem todas as homeoproteínas têm função na determinação de identidade segmentar nos estágios iniciais do desenvolvimento.

Em vertebrados, a família dos genes homeobox foi dividida em duas categorias: o grupo Hox e o grupo órfão. O grupo Hox é o ortólogo do complexo homeótico (HOM-C) em drosófila; os genes pertencentes a esta classe encontram-se em quatro clusters e são responsáveis por definir identidade ao longo do eixo antero-posterior do embrião (MCGinNis \& KRUMLAUF, 1992; FAVIER \& DOLLÉ, 1997). O grupo órfão contém diversos genes dispersos no genoma, envolvidos principalmente com a organogênese (PATTERSON et al., 1998).

\subsection{Regulação de homeoproteínas - as HIPKs}

Com a constatação de que o homeodomínio é uma região altamente conservada entre as homeoproteínas de diversos filos, surgiu a questão: como as homeoproteínas exercem sua alta especificidade in vivo e que regras governam suas habilidades de ativar ou reprimir genes alvo? A especificidade de atuação das homeoproteínas pode ser alcançada por (1) interação com outras proteínas (co-fatores); (2) divergências nas porções amino e carboxi-terminais, que poderiam auxiliar no reconhecimento de genes alvo; ou por

(3) modificações pós-traducionais como fosforilação e acetilação. Particularmente, a 
atividade de fatores de transcrição pode ser regulada de forma rápida e reversível por eventos de fosforilação sítio-específica, promovidos por quinases que agem em cascatas de sinalização ativadas por estímulos extracelulares (KARIN \& HUNTER, 1995).

No trabalho inicial sobre as HIPKs, Kim e colaboradores (1998) descreveram três proteínas, Hipk1, Hipk2 e Hipk3, que possuem em comum o domínio quinase (PK), o de interação com homeoproteínas (HID), a seqüência PEST (uma região de maior susceptibilidade à proteólise - ROGERS et al., 1986), e um domínio rico em histidina e tirosina (YH), localizado na porção carboxi-terminal, de função desconhecida, como esquematizado na figura 2 (KIM et al., 1998).

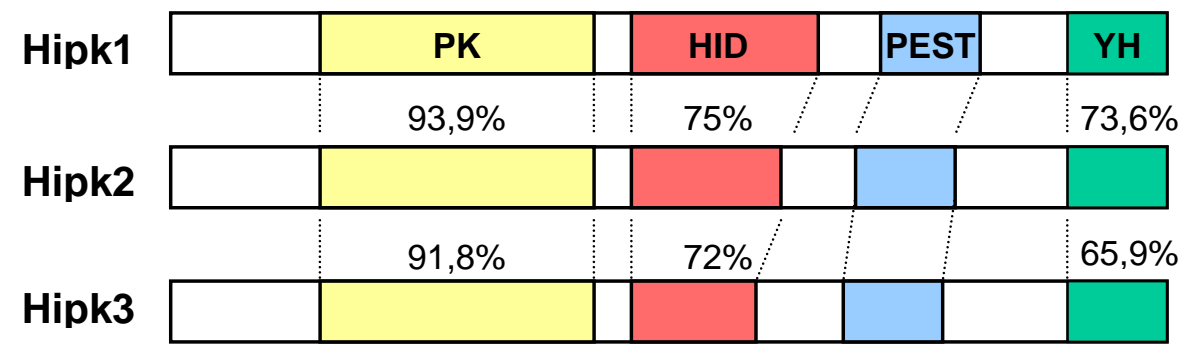

Figura 2. Diagrama esquemático das proteínas Hipk1, Hipk2 e Hipk3. PK, domínio quinase; HID, domínio de interação com homeoproteínas; PEST, seqüência rica em prolina, ácido glutâmico, serina e treonina; e YH, domínio rico em histidina e tirosina. A porcentagem de similaridade entre as diferentes regiões conservadas está indicada. Adaptado de Kim e colaboradores (1998).

Além de interagir com homeoproteínas, Hipk2 é capaz de fosforilar in vitro homeoproteínas NK, sugerindo que as HIPKs poderiam regular a atividade de homeoproteínas in vivo. De fato, a fosforilação de NK3 por Hipk2 provoca aumento na atividade de repressor transcricional daquela proteína (Kim et al., 1998). 


\subsection{A família NK}

As proteínas NKs foram descritas por Kim e Niremberg (1989). Com o propósito de identificar no genoma de drosófila outros genes homeobox, os autores realizaram uma varredura em biblioteca de DNA genômico usando como alvo oligonucleotídeos degenerados do homeobox. Quatro genes foram encontrados e nomeados NK1 a NK4 (NK de Niremberg e $\underline{\text { Kim)}) . ~}$

Os genes $N K$ isolados em drosófila se tornaram mais conhecidos pela denominação de seus fenótipos mutantes: ventral nervous system defective (vnd) para NK2, bagpipe para NK3, tinman para NK4 (revisto por HARVEY, 1996; revisto por STANFEL et al., 2005).

Inúmeras evidências indicam que as NKs são reguladores críticos da organogênese. Assim como os genes do HOM-C em drosófila, as NKs são muito conservadas nos diversos filos e seus ortólogos em vertebrados já foram descritos (revisto por STANFEL et al., 2005).

O ortólogo de tinman (NK4) em camundongos é Nkx2-5 (KomURO \& IZUMO, 1993; LiNTS et al., 1993), e seu papel na morfogênese cardíaca é bem estabelecido. Mutantes $N k x 2.5$ em camundongos chegam a formar o tubo cardíaco, mas o looping, um evento crucial para a morfologia cardíaca, não progride, e o coração destes indivíduos permanece no estágio linear (LYONS et al., 1995). Em humanos, mutações em heterozigose de NKX2-5 foram associadas a malformações cardíacas, como defeitos na formação dos septos atriais e ventriculares (SCHOTT et al., 1998; BENSON et al., 1999).

O gene NK3 (bagpipe) é expresso no mesoderma dorsal, em células destinadas a formarem o mesoderma visceral em drosófila (AZPIAZU \& FRASCH, 1993). Mutações neste gene causam transformação do mesoderme visceral em mesoderme somático e gonadal. De fato, bagpipe regula a expressão de genes necessários para a formação de musculatura visceral (ZAFFRAN \& FRASCH, 2002). 
Hipk2 interage com Nkx2.5 (camundongo) e NK3 (drosófila) in vitro, além de ser capaz de regular, por fosforilação, a atuação de NK3. Por este motivo, suspeita-se que Hipk2 seja importante durante o desenvolvimento embrionário.

\subsection{Estudos de função de Hipk2 durante o desenvolvimento embrionário}

Uma estratégia para avaliar se certa proteína possui função no desenvolvimento é determinar o padrão de expressão espacial e temporal do gene que a codifica em embriões. Assim, em 2002, Pierantoni e colaboradores analisaram a expressão de Hipk2 em embriões de camundongos pela técnica de hibridação in situ. Os resultados mostraram sinais do transcrito somente nas fases mais tardias do desenvolvimento, a partir do $15^{\circ}$ dia pós-coito (dpc), preferencialmente em células da retina, e em tecidos musculares e nervosos. Em adultos, a análise por RT-PCR revelou um padrão amplo de expressão de Hipk2.

A geração de camundongos knockout, ou seja, que não possuem cópias funcionais de genes de interesse, tem sido uma técnica amplamente utilizada para o estudo da função gênica in vivo. Camundongos knockout para os genes Hipk1 e Hipk2 isoladamente são normais e férteis (Kondo et al., 2003; WigGins et al., 2004). No entanto, os duploknockouts $\left(H i p k 1^{-/} / H i p k 2^{-/-}\right)$morrem entre o $9^{\circ}$ e o $12^{\circ}$ dia de gestação, apresentando exencefalia e falha no fechamento do neuróporo anterior (ISONO et al., 2006). A hipótese levantada pelos autores é que Hipk1 e Hipk2 são proteínas de funções muito semelhantes, mutuamente compensatórias.

Além disso, as análises dos camundongos $\mathrm{Hipk}^{-/-} / \mathrm{Hipk}^{+/-}$revelaram que metade dos embriões apresenta costelas ectópicas associadas à sétima vértebra cervical, e não exibem o processo espinhoso da segunda vértebra torácica, um sinal claro de transformação 
posterior, fenômeno comum quando existe alteração na expressão de genes homeóticos. De fato, foram observadas mudanças na expressão de alguns genes Hox e Pax nos mutantes, sugerindo que, direta ou indiretamente, as Hipks além de modular a função de homeoproteínas podem regular a expressão de genes homeobox.

\subsection{Atuação de HIPK2 em outras vias}

Desde sua primeira descrição por Kim e colaboradores (1998), vários estudos vêm identificando diferentes funções para as proteínas HIPKs. Até o momento, sabe-se que as três proteínas possuem características e funções bem parecidas (revisto por CALZADO et al., 2007). No entanto, HIPK2 têm sido a proteína mais bem estudada da família.

A análise por FISH (fluorescent in situ hybridization) mostrou que HIPK2 se localiza na posição 7q32-q34, e esta região está amplificada em tumores do sistema nervoso central, pele e olho, além de estar envolvida em rearranjos cromossômicos de várias neoplasias, como leucemia mielóide aguda, síndrome mielodisplástica, carcinomas de seio, ovário e próstata (HOFMANN et al., 2000).

Outros trabalhos demonstram que, além de interagir com homeoproteínas, HIPK2 pode se associar a várias outras proteínas, principalmente relacionadas ao controle do ciclo celular e apoptose. Entre essas proteínas, citamos TRADD, uma proteína citoplasmática relacionada a respostas apoptóticas (Li et al., 2000); e RanBPM (Ran-binding protein), uma proteína G nuclear envolvida na formação dos microtúbulos durante a mitose (WANG et al., 2002). As funções in vivo dessas associações ainda não foram bem esclarecidas, mas os trabalhos sugerem que HIPK2 pode estabilizar interações entre proteínas e seus co-fatores, eventos estes que podem ser dependentes ou não de sua atividade de quinase. 
HIPK2 fosforila p53, uma proteína supressora de tumor, em resposta à radiação ultravioleta, ionizante ou à exposição a agentes quimioterápicos (WANG et al., 2001; D’ORAZi et al., 2002; Di STEFANO et al., 2004; DAUTH et al., 2007). A fosforilação ocorre na serina 46 (Ser46) de p53, evento que é considerado fundamental para acionar o programa de apoptose regulado por esta proteína (ODA et al., 2000; OKAMURA et al., 2001). O mecanismo de ativação de p53 por HIPK2 é ilustrado na figura 3.

Dados que apontam a participação de outras proteínas na via de p53 são de extremo interesse clínico. Sendo HIPK2 uma proteína ativadora do programa de apoptose, tanto dependente quanto independente de p53, ela pode se tornar um alvo promissor da terapia do câncer. 


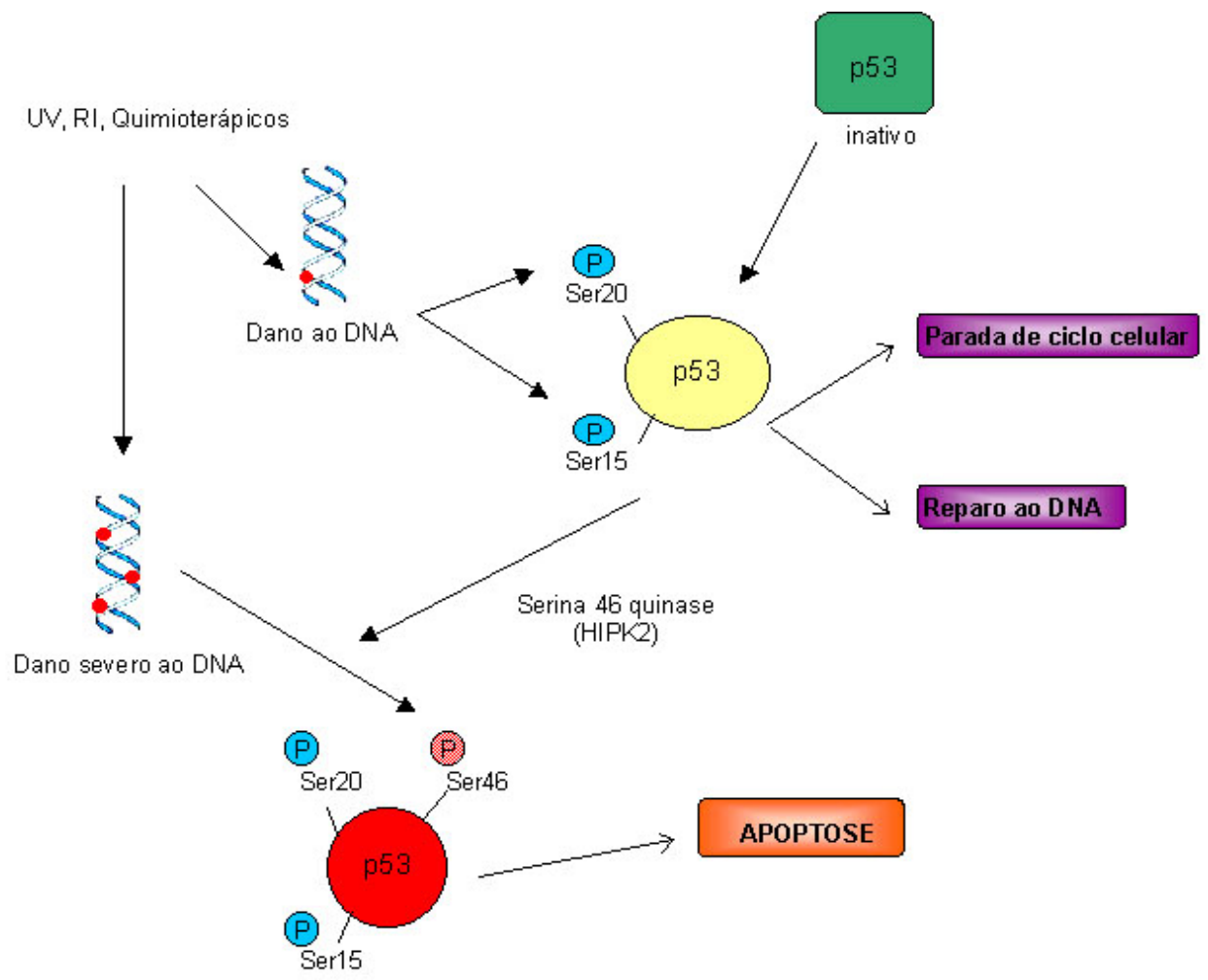

Figura 3. Ativação de p53 em resposta a danos ao DNA. Radiação ultra-violeta (UV), radiação ionizante (RI) e quimioterápicos causam danos ao DNA, ativando vias de sinalização que culminam na fosforilação da Ser15 e Ser20 de p53. Caso o dano à molécula de DNA seja maior do que a capacidade de reparo, ocorrerá ativação de quinases que fosforilam Ser46, o que provoca mudança de conformação da proteína $\mathrm{p} 53$, aumento sua afinidade por promotores específicos de genes apoptóticos, como p53AIP1. Adaptado de Oda e colaboradores (2000) e Dauth e colaboradores (2007). 


\section{OBJETIVOS}

O objetivo geral deste trabalho é contribuir para a elucidação das funções da proteína Hipk2 durante o desenvolvimento embrionário.

Especificamente, pretende-se:

(1) determinar o padrão temporal e espacial de expressão de Hipk2 durante o desenvolvimento embrionário. Pierantoni e colaboradores (2002) afirmaram que o gene se expressava tardiamente em camundongos, somente a partir do $15^{\circ}$ dpc. No entanto, como Hipk2 é capaz de interagir e fosforilar homeoproteínas in vitro, é possível que seu transcrito seja encontrado em fases mais precoces da embriogênese. Assim, uma análise aprofundada se faz necessária;

(2) estabelecer um modelo experimental para se estudar as diferentes vias de atuação de HIPK2 em humanos. Através do silenciamento de HIPK2 por RNAi (RNA de interferência) em cultura de células humanas, pode-se avaliar o papel deste na regulação (direta ou indireta) de diferentes genes e proteínas, em particular de genes homeobox. 


\subsection{Estudo da expressão de Hipk2 durante o desenvolvimento}

3.1.1. Escolha e obtenção da sonda de RNA (ribossonda) para hibridação in situ

Quatro regiões do transcrito de Hipk2 foram escolhidas como locais para ribossondas. Como critérios para seleção da região foram levados em consideração o tamanho do fragmento gerado (até $500 \mathrm{pb}$ ) e a exclusividade da seqüência de Hipk2, que não deveria apresentar homologia com nenhum outro transcrito de camundongo.

As ribossondas utilizadas nas reações de hibridação in situ foram obtidas por RTPCR (reação em cadeia da polimerase após transcrição reversa) a partir do RNA total de tecidos embrionários de camundongos $(17.5 \mathrm{dpc})$. O protocolo para extração de RNA e a síntese do cDNA utilizado como molde para as RT-PCRs se encontram nos itens a seguir.

\subsubsection{Extração de RNA}

O RNA foi extraído de 50-100 mg de tecido com TRIzol ® Reagent (Invitrogen), de acordo com protocolo do fabricante. O RNA foi ressuspendido em $50 \mu 1$ de água DEPC $\left(\mathrm{H}_{2} \mathrm{O}\right.$ Deionizada tratada com $0,1 \%$ dietilpirocarbonato - DEPC - USB), quantificado no espectrofotômetro Gene Quant Pro (GE Healthcare) e armazenado a $-70^{\circ} \mathrm{C}$. 


\subsubsection{Reverse Transcriptase - PCR (RT-PCR)}

A síntese de cDNA (DNA complementar) foi feita a partir de $2 \mu \mathrm{g}$ de RNA total dos tecidos fetais de camundongos, utilizando o kit Superscript III Reverse Transcriptase (Invitrogen), com $0,5 \mu \mathrm{g}$ do iniciador $\mathrm{d}(\mathrm{T})$ ou $0,2 \mu \mathrm{g} d(\mathrm{~N})$, segundo instruções do fabricante.

Para a reação de amplificação, o cDNA foi diluído em uma proporção de 1:10 e $1 \mu 1$ foi usado na PCR, juntamente com 2,5 $\mu \mathrm{mol}$ dos iniciadores senso e antisenso, tampão 1X, 1 unidade de Taq Polymerase (GE Healthcare) e 1,25mM de dNTPs.

A tabela 1 mostra a seqüência de cada iniciador testado, as temperaturas de anelamento das reações, e o tamanho dos fragmentos gerados. A amplificação foi realizada no termociclador Peltier Thermal Cycler (MJ Research), e o programa de ciclagem utilizado foi $94^{\circ} \mathrm{C}$ por três minutos, 34 ciclos de $\left(94^{\circ} \mathrm{C}\right.$ por 45 segundos, as temperaturas de anelamento especificadas na tabela 1 durante 1 minuto, e $72^{\circ} \mathrm{C}$ por um minuto) e um tempo adicional de extensão $\left(\mathrm{a} 72^{\circ} \mathrm{C}\right)$ de cinco minutos. Os resultados das amplificações foram visualizados em gel de agarose $1 \%$, corado com brometo de etídio $0,5 \mu \mathrm{g} / \mathrm{ml}$.

\begin{tabular}{|c|c|c|c|}
\hline Iniciadores & Seqüência $5^{\prime}-3^{\prime}$ & F (pb) & $\mathrm{T}\left({ }^{\circ} \mathrm{C}\right)$ \\
\hline $\begin{array}{l}\mathrm{D} \\
\mathrm{T}\end{array}$ & $\begin{array}{l}\text { TGCAAGCGCCGGGTGAATA } \\
\text { GCTGTACAGATGTGTGGGT }\end{array}$ & 550 & 60 \\
\hline $\begin{array}{l}\mathrm{S} \\
\mathrm{R}\end{array}$ & $\begin{array}{c}\text { AGGGGCTGCTGCTGCTGGAA } \\
\text { TCCACGACTCTCССТАCT }\end{array}$ & 356 & 60 \\
\hline $\begin{array}{c}\mathrm{I} \\
\mathrm{SO}\end{array}$ & $\begin{array}{c}\text { CATGGCAGGCACTCAGC } \\
\text { GCTGCAAGCTGGGCTG }\end{array}$ & 334 & 58 \\
\hline $\begin{array}{l}\text { 3'UTR F } \\
\text { 3'UTR R }\end{array}$ & $\begin{array}{l}\text { AGTCAGTATCCAGCCCAGTT } \\
\text { ATAGATTTCCCCTCCTTACC }\end{array}$ & 331 & 55 \\
\hline
\end{tabular}

Tabela 1: Iniciadores utilizados na obtenção de ribossondas para hibridação in situ. Para cada par de iniciadores, à direita se encontram o tamanho do fragmento gerado $(\mathrm{F})$ e a temperatura de anelamento $\left(\mathrm{T}^{\circ} \mathrm{C}\right)$ das reações de PCR. 


\subsubsection{Clonagem dos fragmentos em pGEM}

Cada fragmento gerado foi clonado no vetor pGEM T-Easy (Promega), conforme instrução do fabricante. O plasmídeo resultante foi usado na transformação de bactérias competentes.

\subsubsection{Transformação da ligação em bactérias}

Alíquotas de $100 \mu \mathrm{l}$ de bactérias competentes (DH10B) foram descongeladas e a cada uma delas foi adicionado o volume total da ligação. As misturas foram mantidas em gelo por 30 minutos. Em seguida, as bactérias foram colocadas a $37^{\circ} \mathrm{C}$ por 1 minuto e novamente no gelo por 2 minutos. Após adicionar $0,5 \mathrm{ml}$ de meio de cultura LB (10g de peptona, $5 \mathrm{~g}$ de extrato de levedura e $10 \mathrm{~g}$ de $\mathrm{NaCl}$ para um volume de 1 litro), as bactérias foram incubadas a $37^{\circ} \mathrm{C}$ por 45 minutos e então plaqueadas em LB-Ágar com $100 \mu \mathrm{g} / \mathrm{ml}$ de ampicilina. As placas foram incubadas por $14-16 \mathrm{~h}$ a $37^{\circ} \mathrm{C}$.

\subsubsection{Preparação do plasmídeo em pequena escala (miniprep)}

Colônias isoladas de bactérias contendo os plasmídeos de interesse foram inoculadas em $3 \mathrm{ml}$ de $\mathrm{LB}$ contendo $100 \mu \mathrm{g} / \mathrm{ml}$ de ampicilina, e incubadas a $37^{\circ} \mathrm{C}$ durante 14-16h sob agitação. O plasmídeo foi isolado utilizando o Fast Plasmid Kit (Eppendorf), conforme orientação do fabricante. O DNA plasmideal foi ressuspendido em $50 \mu 1$ de água deionizada contendo 20ng/ $\mu$ l de RNase. 


\subsubsection{Digestão com enzimas de restrição}

Os plasmídeos contendo os insertos de interesse foram digeridos com a enzima de restrição Eco RI (GE Healthcare), na proporção de 2 unidades por $1 \mu \mathrm{g}$ de DNA por 2 horas. O produto da digestão foi visualizado em gel de agarose $1,5 \%$ corado com brometo de etídio. A banda correspondente ao fragmento foi purificada do gel com o kit Perfectprep Gel Cleanup (Eppendorf) e quantificada em gel de agarose 1\% com o marcador de peso molecular low mass ladder (Invitrogen).

\subsubsection{Clonagem em pBluescript}

Os fragmentos foram subclonados em pBluescript (Stratagene) previamente digerido com EcoRI (GE Healthcare). Para a ligação entre o produto de interesse e o vetor em questão utilizou-se $10 \eta$ g do último e uma proporção molar de 3 e 6 vezes mais do fragmento de interesse.

A ligação foi feita utilizando T4 ligase (New England Biolabs) a $15^{\circ} \mathrm{C}$ por 16 horas, segundo instruções do fabricante. Em seguida, ela foi transformada em bactérias competentes; o plasmídeo foi purificado e sua orientação foi confirmada por digestão com as enzimas de restrição, conforme os protocolos exibidos nos tópicos 3.1.1.4., 3.1.1.5. e 3.1.1.6., respectivamente. Além das digestões com enzimas de restrição, foram feitas reações de seqüenciamento para conferir a integridade dos fragmentos. 


\subsubsection{Seqüenciamento de plasmídeos}

Para as reações de seqüenciamento dos clones utilizou-se o DYEnamic ET Dye Terminator Cycle Sequencing Kit (GE Healthcare), específico para o aparelho MegaBACE $^{\mathrm{TM}} 1000$ (GE Healthcare). Foram utilizados $4 \mu \mathrm{l}$ do mix do kit de seqüenciamento, $0,5 \mu \mathrm{g}$ de plasmídeo e $0,25 \mu \mathrm{M}$ do iniciador específico (T3 -5' ATTAACCCTCACTAAAGGGA 3' ou T7 - 5' TAATACGACTCACTATAGGG 3') em um volume final de $10 \mu 1$. A reação foi precipitada com $1 \mu 1$ de acetato de amônia e $30 \mu 1$ de etanol $95 \%$. Os tubos foram centrifugados por 15 minutos a $12000 \mathrm{rpm}$ e o sobrenadante foi aspirado. Aos tubos foram adicionados $100 \mu \mathrm{l}$ de etanol $70 \%$, seguido de nova centrifugação de 12000rpm por 5 minutos, e o sobrenadante foi removido. O precipitado foi seco por 1 minuto a $95^{\circ} \mathrm{C}$ e ressuspendido em tampão fornecido pelo kit.

3.1.1.9. Preparação de plasmídeo em média escala (midiprep) e purificação do plasmídeo

Foi feita preparação em média escala (midiprep), utilizando o kit Perfect Plasmid Midi (Eppendorf), segundo instruções do mesmo. Em seguida, o plasmídeo foi quantificado em espectrofotômetro e $6 \mu \mathrm{g}$ foram linearizados com as enzimas de restrição NotI (New England Biolabs) ou XhoI (GE Healthcare). Os produtos desta digestão foram visualizados em gel de agarose $1 \%$ corado com brometo de etídio $0,5 \mu \mathrm{g} / \mathrm{ml}$.

O plasmídeo linearizado foi submetido a um tratamento com proteinase $\mathrm{K}$ $(100 \mu \mathrm{g} / \mathrm{ml})$ para eliminar atividades de RNAses durante 2 horas a $65^{\circ} \mathrm{C}$. A reação foi interrompida por extrações fenol:clorofórmio (1:1) e clorofórmio 100\%, e o DNA 
linearizado foi precipitado pela adição de $10 \%$ do volume de acetato de sódio $3 \mathrm{M} \mathrm{pH} \mathrm{5,2} \mathrm{e}$ $4 \mathrm{X}$ volume de etanol $100 \%$. A mistura foi deixada por pelo menos trinta minutos a $-80^{\circ} \mathrm{C}$ e em seguida centrifugada a $14000 \mathrm{rpm}$ por meia hora a $4^{\circ} \mathrm{C}$. O precipitado foi seco e ressuspendido em água tratada com dietilpirocarbonato $\left(\mathrm{H}_{2} \mathrm{O}\right.$ DEPC), numa concentração final de $1 \mu \mathrm{g} / \mu \mathrm{l}$.

\subsubsection{Transcrição in vitro - síntese da ribossonda}

A síntese de RNA foi feita utilizando o kit Maxiscript (Ambion). Para cada $1 \mu 1$ do plasmídeo linearizado foram adicionados $1 \mathrm{X}$ tampão de transcrição, $2 \mu \mathrm{l}$ de mix de nucleotídeos marcados com digoxigenina (Roche), $1 \mu 1$ de inibidor de RNAse (RNAsinPromega), $2 \mu \mathrm{LTT} 100 \mathrm{mM}, 10$ unidades de RNA polimerase e $10 \mu \mathrm{lde} \mathrm{H}_{2} \mathrm{O}$ DEPC, num volume final de $20 \mu 1$. Essa reação foi incubada a $37^{\circ} \mathrm{C}$ por duas horas. Em seguida, foram adicionadas 2 unidades de DNAse I (Promega), e a reação prosseguiu a $37^{\circ} \mathrm{C}$ por mais quinze minutos. A síntese foi interrompida acrescentando-se $2 \mu 1$ de EDTA 0,2M pH 8.0.

Para precipitação do RNA, foram adicionados $5 \mu 1$ de acetato de sódio 3M pH 5.2 e $150 \mu \mathrm{l}$ de etanol $100 \%$, e estes foram mantidos a $-80^{\circ} \mathrm{C}$ por 30 minutos. Em seguida, foi feita uma centrifugação de 14000 rpm por 30 minutos a $4^{\circ} \mathrm{C}$. O precipitado contendo o RNA foi seco e ressuspendido em $90 \mu \mathrm{l}$ de $\mathrm{H}_{2} \mathrm{O}$ DEPC (aproximadamente $0,1 \mu \mathrm{g} / \mu \mathrm{l}$ ). Uma alíquota de cada tubo foi usada para checagem em gel de agarose $1 \%$, corado com brometo de etídio, e o restante foi guardado a $-70^{\circ} \mathrm{C}$. 


\subsubsection{Obtenção de embriões de camundongos}

Embriões de camundongos da linhagem C57/B16 foram coletados entre os dias 9.5 e 17.5 após a fertilização (dpc), contados a partir da 0 hora do dia em que se observou a presença de plug vaginal (tampão mucoso na abertura da vagina) nas fêmeas.

\subsubsection{Processamento dos embriões}

Os embriões foram coletados em solução PBS-DEPC $2.7 \mathrm{mM}(\mathrm{KCl}, 1.4 \mathrm{mM}$ KH2PO4, 4.3mM Na2HPO4 · 12H2O, $137 \mathrm{mM} \mathrm{NaCl} \mathrm{pH} 7,4$, tratado com 0,1\% de DEPC) e desidratados em solução de 30\% sacarose em PBS-DEPC. Em seguida, os espécimes foram fixados em 4\% paraformaldeído (PFA) durante 12 horas.

Cada embrião foi emblocado em Tissue Tek (O.C.T. Compound - Sakura) e cortes sagitais, parassagitais e transversais de $12 \mu \mathrm{m}$ de espessura foram feitos em criostato. Os cortes foram organizados em lâminas (Superfrost Plus Slides - Fisher Scientific) e armazenados em freezer $-80^{\circ} \mathrm{C}$ até sua utilização nas hibridações in situ.

\subsubsection{Hibridação in situ em cortes de embriões}

As lâminas foram descongeladas a $55^{\circ} \mathrm{C}$ por 15 minutos. Após completa secagem, elas foram fixadas com PFA 4\% e glutaraldeído/PBS 0,2\%, a temperatura ambiente (TA) por 10 minutos. Em seguida, os cortes foram lavados por três vezes de cinco minutos cada com PBT (PBS $+0,1 \%$ Tween 20); acrescentou-se então $\mathrm{H}_{2} \mathrm{O}_{2} /$ PBT por 10 minutos para 
clareamento dos cortes. Após o tratamento, as lâminas foram lavadas por três vezes de cinco minutos a TA com PBT. As lâminas foram então tratadas com $10 \mu \mathrm{g} / \mathrm{ml}$ de proteinase $\mathrm{K}$ em PBT por 2 minutos, e a reação foi interrompida com $2 \mathrm{mg} / \mathrm{ml}$ de glicina/PBT por 10 minutos a TA. As lâminas foram novamente fixadas com PFA $4 \%$ e $0,2 \%$ de glutaraldeído/PBS a TA por 10 minutos, e lavadas três vezes com PBT por cinco minutos a TA. Os cortes foram incubados a $65^{\circ} \mathrm{C}$ com solução de pré-hibridação (formamida $50 \%$, 5X SSC, heparina $50 \mu \mathrm{g} / \mathrm{ml}$, RNAt $50 \mu \mathrm{g} / \mathrm{ml}$ - Invitrogen - e SDS 1\%) por uma hora. Posteriormente, foi adicionada aos cortes a solução de hibridação (solução de préhibridação + ribossonda); as lâminas foram cobertas com parafilm e colocadas em por aproximadamente 16 horas a $65^{\circ} \mathrm{C}$.

No dia seguinte, as lâminas foram lavadas por três vezes com a Solução 1 (formamida $50 \%$, SSC $6 \%$ e SDS $1 \%$ ), por 15 minutos cada, a $65^{\circ} \mathrm{C}$. Em seguida, foram lavadas três vezes de 15 minutos a $65^{\circ} \mathrm{C}$ com a Solução 2 (formamida $50 \%$, SSC 2,4\%). Os cortes foram lavados por três vezes de cinco minutos a TA com a solução de $\mathrm{MAB}_{\mathrm{Lev}, \mathrm{Tw}}$ (100mM ácido maléico, $15 \mathrm{mM} \mathrm{NaCl}, 2 \mathrm{mM}$ Levamisole e 0,1\%Tween 20, pH7,5). As lâminas foram então incubadas por 2 horas com solução de alta concentração protéica ( $10 \%$ soro de ovelha inativado e $2 \%$ BMB blocking solution - Boehringer - em tampão $\mathrm{MAB}_{\mathrm{Lev}, \mathrm{Tw}}$ ) a TA, a fim de bloquear ligações inespecíficas do anticorpo. Finalmente, os cortes foram tratados com anticorpo anti-digoxigenina 1:2000 em $\mathrm{MAB}_{\mathrm{Lev}, \mathrm{Tw}}$ com soro de ovelha $10 \%$ a $4^{\circ} \mathrm{C}$ por 16 horas.

No terceiro dia, as lâminas foram lavadas seis vezes com $\mathrm{MAB}_{\mathrm{Lev}, \mathrm{Tw}}$, três vezes por cinco minutos a TA e três vezes de 30 minutos, e deixados por 16 horas em MAB $\mathrm{B}_{\mathrm{Lev}, \mathrm{Tw}}$ a $4^{\circ} \mathrm{C}$.

As lâminas foram tratadas com a solução de NTMT (100mM NaCl, 100mM Tris pH9.5, 50mM $\mathrm{MgCl}_{2}, 0,1 \%$ Tween 20, 2mM Levamisole) por três vezes de dez minutos a 
TA. Em seguida, foram incubadas em recipiente protegido da luz com substrato para a fosfatase alcalina, BCIP/NBT (117 $\mu \mathrm{g} / \mathrm{ml} \mathrm{BCIP,} 225 \mu \mathrm{g} / \mathrm{ml}$ NBT em NTMT), ou BM Purple (2mM Levamisole, 0,1\% Tween 20 em BM Purple - Boehringer). A reação foi interrompida com lavagens de PBS por 1 hora e em seguida os cortes foram fixados em 4\% PFA a $4^{\circ} \mathrm{C}$. As lâminas foram cobertas com lamínulas em solução de glicerol 50\% em PBS e analisadas e fotografadas no microscópio (Nikon Eclipse E600 - Image Pro Plus).

\subsection{Efeito do silenciamento (knockdown) de HIPK2 por shRNA (short hairpin RNA) em cultura celular}

\subsubsection{Desenhos dos oligonucleotídeos e clonagem em pSuper}

Para desenho dos oligonucleotídeos de $19 \mathrm{pb}$ a serem utilizados no silenciamento de HIPK2 foram consultados programas disponíveis na Internet: RNAi Design 3.6 (http://www.changbioscience.com/stat/sirna.html), Genescript siRNA design (https://www.genscritp.com/ssl-bin/app/rnai) e Wistar Institute siRNA selector (http://hydra1.wistar.upenn.edu/Projects/siRNA/siRNAindex.htm). As seqüências obtidas foram analisadas pelo programa BLAST, a fim de excluir aquelas que apresentassem homologia com outros genes ou EST humanos. Os oligonucleotídeos com as seqüências alvo para silenciamento de HIPK2 estão listados na tabela 2. A seqüência OLIGO S já havia sido utilizada com êxito no trabalho de Di Stefano e colaboradores (2004), e por esta razão foi incluída nos experimentos subseqüentes.

O anelamento dos oligonucleotídeos chamados For e Rev foi feito utilizando 50 ฤg de cada, tampão de anelamento (100mM tris pH8.0, 50mM $\left.\mathrm{MgCl}_{2}\right)$ para um volume final 
de $50 \mu 1$, e as seguintes condições: $88^{\circ} \mathrm{C}$ por dois minutos, $65^{\circ} \mathrm{C}$ por 10 minutos, $37^{\circ} \mathrm{C}$ por 10 minutos, temperatura ambiente por 1 hora.

\begin{tabular}{|c|c|}
\hline OLIGO 3 & $\begin{array}{l}\text { For } \\
\text { 5'gatccccGACACCAGATGACCATGAAttcaagagaTTCATGGTCATCTGGTGTCttttggaaa3' } \\
\text { Rev } \\
\text { 5'agctttccaaaaaGACACCAGATGACCATGAAtctcttgaaTTCATGGTCATCTGGTGTCggg3' }\end{array}$ \\
\hline OLIGO 4 & $\begin{array}{l}\text { For } \\
5 \text { 'gatccccGCACCAGTCATCTGTGAGAttcaagagaTCTCACAGATGACTGGTGCttttggaaa3' } \\
\text { Rev } \\
\text { 5'agcttttccaaaaaGCACCAGTCATCTGTGAGAtctcttgaaTCTCACAGATGACTGGTGCggg3 }\end{array}$ \\
\hline OLIGOS & $\begin{array}{l}\text { For } \\
\text { 5'gatccccGAAAGTACATTTTCAACTGttcaagagaCAGTTGAAAATGTACTTTCttttggaaa3' } \\
\text { Rev } \\
\text { 5'agctttccaaaaaGAAAGTACATTTTCAACTGtctcttgaaCAGTTGAAAATGTACTTTCggg3' }\end{array}$ \\
\hline
\end{tabular}

Tabela 2: Oligonucleotídeos desenhados e sintetizados a partir da seqüência de HIPK2 para expressão de shRNA. Em vermelho, as seqüências específicas do transcrito de HIPK2, e entre elas se encontra uma região espaçadora para formar o loop do hairpin. As extremidades possuem sítios de restrição para as enzimas Bgl II e Hind III.

Os oligonucleotídeos anelados foram ligados ao vetor de supressão de expressão em mamíferos pSuper (OligoEngine), previamente digerido com 30 unidades das enzimas Bgl II (New England Biolabs) e Hind III (GE Healthcare), gerando extremidades coesivas para ligação com os oligonucleotídeos. Cinqüenta nanogramas do vetor foram ligados a 


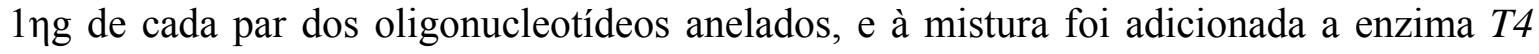
ligase (New England Biolabs), juntamente com o tampão próprio. Os tubos foram mantidos a $16^{\circ} \mathrm{C}$ por aproximadamente 16 horas. Os procedimentos para inserção dos plasmídeos resultantes em bactérias competentes e sua posterior extração por kit para minipreps encontram-se nos itens 3.1.1.4. e 3.1.1.5., respectivamente.

Os plasmídeos foram digeridos com as enzimas de restrição BamHI (GE Healthcare) e Hind III (GE Healthcare). O produto da digestão foi visualizado em gel de agarose $2 \%$, e os clones positivos foram seqüenciados. Como o vetor em questão ( $p S$ uper) também possui as regiões promotoras $\mathrm{T} 3$ e $\mathrm{T} 7$, o protocolo de sequenciamento dos plasmídeos foi realizado exatamente como descrito no tópico 3.1.1.8.

\subsubsection{Preparação de plasmídeo em larga escala (Maxiprep)}

Uma colônia isolada de cada construção e também de bactérias transformadas com pSuper original (usado com controle negativo nos experimentos subseqüentes) foi inoculada em meio LB contendo $100 \mu \mathrm{g} / \mathrm{ml}$ de ampicilina, e incubada a $37^{\circ} \mathrm{C}$ durante aproximadamente 8 horas sob agitação. Uma alíquota desses pré-inóculos foi re-inoculada em $100 \mathrm{ml}$ de LB contendo $100 \mu \mathrm{g} / \mathrm{ml}$ de ampicilina e incubada durante $14-16$ horas sob agitação a $37^{\circ} \mathrm{C}$. A partir dessas culturas, o DNA plasmideal foi obtido em larga escala utilizando o EndoFree Plasmid Maxi Kit (Qiagen), conforme orientações do fabricante. 


\subsubsection{Transfecção de células 293 EBNA}

Células embrionárias de rim humano (293 EBNA) foram cultivadas em meio DMEM, suplementado com 10\% de soro fetal bovino (FBS - Cultilab), 1\% de L-glutamina 200mM (Invitrogen) e 1\% de penicilina-estreptomicina (Sigma), e mantidos em estufa a $37^{\circ} \mathrm{C}$ e $5 \%$ de $\mathrm{CO}_{2}$.

Quando atingiram confluência, as células foram lavadas com DPBS (Dulbecco's PBS - Gibco/Invitrogen) e tripsinizadas (0,25\% tripsina-0,02\% EDTA - Invitrogen) por 2 minutos a $37^{\circ} \mathrm{C}$ e $5 \% \mathrm{CO}_{2}$. A digestão foi interrompida com a adição de meio de cultura com soro e as células foram transferidas para um tubo plástico de $15 \mathrm{ml}$, de onde uma alíquota foi retirada para contagem das células em câmara de Neubauer (Knittel Gläser).

Cerca de $2,5.10^{5}$ células foram transferidas para placas isoladas. No dia seguinte, cada grupo de células foi transfectado com uma das três construções para suprimir HIPK2 endógena por RNAi, mais um vetor de resistência à puromicina pBabe-PURO gentilmente cedido pela Profa. Dra. Luciana Vasques $(28 \mu \mathrm{g}$ de cada construção ou de $p$ Super sem oligo,

e $0,2 \mu \mathrm{g}$ de pBabe PURO), utilizando lipofectamina (kit LipofectAMINE PLUSGibco/Invitrogen), conforme orientações do fabricante.

Durante um período de seleção de 10 dias (adicionando 250ng/ml de puromicina ao meio de cultura), os clones celulares foram coletados e transferidos para placas de 6 poços até atingirem uma confluência onde fosse possível extrair o DNA genômico e o RNA. 


\subsubsection{Descongelamento das células}

A ampola criogênica contendo as células foi retirada do nitrogênio líquido e descongelada por 2 minutos a $37^{\circ} \mathrm{C}$. O conteúdo foi misturado cuidadosamente num tubo plástico de $15 \mathrm{ml}$ juntamente com $5 \mathrm{ml}$ de meio de cultura, e a mistura foi centrifugada durante 5 minutos a TA a 1000rpm. O sobrenadante foi descartado e o precipitado foi ressuspendido em meio de cultura (especificado acima) e plaqueado em garrafa de área específica para a quantidade de células congeladas. A garrafa foi colocada em estufa de $\mathrm{CO}_{2}$ a $37^{\circ} \mathrm{C}$ e, após 5 minutos, o conteúdo foi levemente agitado para que as células aderissem por igual por toda a área da garrafa. A garrafa foi então devolvida à estufa.

\subsubsection{Congelamento das células}

As células cultivadas foram lavadas com DPBS (Gibco/Invitrogen) e tripsinizadas a $37^{\circ} \mathrm{C}$ e $5 \% \mathrm{CO}_{2}$. Após 2 minutos, o conteúdo foi centrifugado a 1000 rpm por 5 minutos, o sobrenadante foi descartado e o precipitado foi ressuspendido em meio de congelamento (10\% DMSO, 20\% soro fetal bovino e 70\% DMEM), em volume final de $1 \mathrm{ml}$. As células foram transferidas para tubos criogênicos e estes foram colocados a $-70^{\circ} \mathrm{C}$ por até um mês. Por fim, os tubos com as células foram armazenados em nitrogênio líquido. 


\subsubsection{Extração de DNA das células}

Quando o poço da placa de seis poços apresentava mais de $70 \%$ de confluência, $1 / 10$ das células era separado em um tubo de $1,7 \mathrm{ml}$ e centrifugado por 5 minutos a $10.000 \mathrm{rpm}$. O sobrenadante foi descartado, e ao pellet de células foi adicionado $700 \mu 1$ de tampão de lise $(100 \mathrm{mM}$ Tris-HCl pH8,5; 5mM EDTA; 0,2\% SDS; $200 \mathrm{mM} \mathrm{NaCl} ; 100 \mu \mathrm{g} / \mathrm{ml}$ Proteinase K - Invitrogen). A amostra foi então incubada por 16 horas à $37^{\circ} \mathrm{C}$. Em seguida, $700 \mu 1$ de isopropanol foram adicionados ao tubo, que foi então deixado a $-20^{\circ} \mathrm{C}$ por pelo menos 30 minutos para precipitação do DNA. Após uma centrifugação de 15 minutos a 13000rpm, o pellet de DNA foi lavado com $500 \mu 1$ de etanol $70 \%$. Depois de uma nova centrifugação, retirou-se o etanol, o precipitado foi seco a temperatura ambiente e o DNA foi ressuspendido em $50 \mu \mathrm{l}$ de $\mathrm{H}_{2} \mathrm{O}$.

\subsubsection{Verificação de clones celulares positivos}

Dois microlitros de DNA genômico extraído das células transfectadas foram usados numa PCR, utilizando 2,5 $\mu$ mol de cada um dos iniciadores T3 e T7, juntamente com o tampão específico, 1 unidade de Taq Polimerase e 1,25mM de dNTP. As condições de ciclagem foram: $94^{\circ} \mathrm{C}$ por 3 minutos, 34 ciclos de $\left(94^{\circ} \mathrm{C}\right.$ por 45 segundos, $55^{\circ} \mathrm{C}$ por 1 minuto, $72^{\circ} \mathrm{C}$ por 45 segundos), mais um tempo de extensão adicional de 3 minutos a $72^{\circ} \mathrm{C}$. Os resultados foram visualizados em gel de agarose $2 \%$, corados com brometo de etídio $0,5 \mu \mathrm{g} / \mathrm{ml}$. 


\subsubsection{Análise da expressão gênica nas células transfectadas}

Quando os clones celulares confluíram num poço de placa de 6 poços, metade das células foi transferida para um tubo de $1,7 \mathrm{ml}$, das quais se extraiu o RNA utilizando o RNeasy mini kit, conforme protocolo do fabricante (Qiagen). A síntese de cDNA foi realizada conforme detalhado no item 3.1.1.2.

Duas abordagens foram realizadas para conferirmos o silenciamento de HIPK2 e os níveis de expressão de outros genes: RT-PCR semi-quantitativa e RT-PCR em tempo real (Real Time PCR). Nas reações de RT-PCR semi-quantitativas, utilizamos as seguintes condições de ciclagem: $94^{\circ} \mathrm{C}$ por 3 minutos, mais $\left(94^{\circ} \mathrm{C}\right.$ por 45 segundos, $60^{\circ} \mathrm{C}$ por 1 minuto, $72^{\circ} \mathrm{C}$ por 1 minuto) pelo número de ciclos mínimo onde era possível observar amplificação sem saturar a reação, e um tempo de extensão adicional de 3 minutos a $72^{\circ} \mathrm{C}$.

Os iniciadores utilizados nestas reações foram: HIPK2 (For 5'TGCAAGCGCCGGGTGAATA-3' e Rev 5'-GCTGTACAGATGTGTGGGT-3') e GAPDH (For 5'-CTGCACCACCAACTGCTTA-3' e Rev 5'CTAGACGGCAGGTCAGGTC-3').

\subsubsection{RT- PCR em tempo real (Real Time-PCR)}

A lista com as seqüências dos iniciadores utilizados nas RT-PCRs em tempo real encontra-se na tabela 3 .

Antes da análise de expressão gênica nos clones, foram feitos testes de validação, para determinar se as eficiências de amplificação dos genes alvo e controle endógeno eram aproximadamente iguais. Para análise dos resultados, foi utilizado como referência o guia 
disponibilizado pela empresa do equipamento (User Bulletin \#2: Relative Quantification of Gene Expression, da Applied Biosystems).

\begin{tabular}{|c|c|}
\hline Iniciador & Seqüência $5^{\prime}-3^{\prime}$ \\
\hline GAPD For & CTCTCTGCTCCTCCTGTTCGAC \\
\hline GAPD Rev & TGAGCGATGTGGCTCGGCT \\
\hline HPRT1 For & TTCCTTGGTCAGGCAGTATAATCC \\
\hline HPRT1 Rev & GGTCCTTTTCACCAGCAAGCT \\
\hline HMBS For & CTGGAAGGAGGCTGCAGTGT \\
\hline HMBS Rev & TACAGTTGCCCATCCTTCATAGC \\
\hline HIPK1 For & CAGTCACGTTACTACAGAGCTCCTGA \\
\hline HIPK1 Rev & AGCACCATAAAGAGGCCAT \\
\hline HIPK2 For & CCCGGCTTCCAAGGCTT \\
\hline HIPK2 Rev & TTCCATTCGCACCGAGTAGC \\
\hline HIPKЗ For & GAGACCGAATAGTATGTCAGATGAAGAG \\
\hline HIPКЗ Rev & ATGCCCGGAAGAGTCAGATG \\
\hline PAX6 For & GAAAGGATGCCTCATAAAGGGG \\
\hline PAX6 Rev & GGGCTCTGAAATCTCGGATGTC \\
\hline NKX 2.5 For & GCCGAAAAGAAAGAGCTGTG \\
\hline NKX $2.5 \mathrm{Rev}$ & AGGTACCGCTGCTGCTTG \\
\hline NKX 3.1 For & CAGAGACCGAGCCAGAAAGG \\
\hline NKX $3.1 \mathrm{Rev}$ & CTCGATCACCTGAGTGTGGGA \\
\hline NKX 6.1 For & CCTGTACCCCTCATCAAGGA \\
\hline NKX $6.1 \mathrm{Rev}$ & CAACGAATAGGCCAAACGAG \\
\hline
\end{tabular}

Tabela 3: Iniciadores utilizados nas reações de PCR em tempo real (Real Time-PCR). 
Nos experimentos de validação, foi utilizada a concentração de iniciadores recomendada pelo guia de referência do aparelho (50ๆmol). Foram submetidas às reações

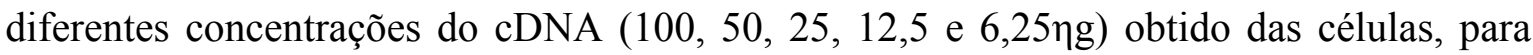
que pudéssemos definir uma concentração ótima para reação. No caso, $25 \eta$ g foram suficientes, e essa concentração foi utilizada nos experimentos posteriores.

Nos experimentos de RT-PCR em tempo real usamos o intercalador SyBR Green e a plataforma ABIPRISM® 7500 Sequence Detection System (Applied Biosystems). A amplificação foi realizada em placas ópticas de 96 poços (Applied Biosystems), e todas as reações foram feitas em triplicatas. A reação foi feita com 12,5 $\mu 1$ de SyBR Green PCR

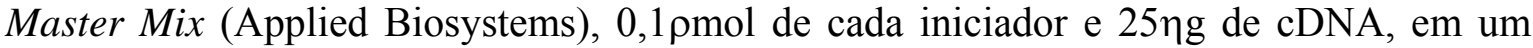
volume final de $25 \mu 1$. As condições de ciclagem foram: $50^{\circ} \mathrm{C}$ por 2 minutos, $95^{\circ} \mathrm{C}$ por 10 minutos e 40 ciclos de $\left(95^{\circ} \mathrm{C}\right.$ por 15 segundos, $60^{\circ} \mathrm{C}$ por 1 minutos $)$. A análise dos dados foi feita pelo programa do equipamento (7500 System SDS Software - Applied Biosystems). Foram utilizados como controles endógenos das amplificações os genes HPRT1, HMBS e GAPD.

Ao final de cada reação, sempre era realizada uma curva de dissociação, como controle da presença de contaminações e/ou primer-dimers. 


\subsection{Perfil de expressão de Hipk2 durante o desenvolvimento embrionário}

\subsubsection{Síntese da ribossonda para as reações de hibridação in situ}

Quatro regiões do transcrito de Hipk2 foram selecionadas como potenciais locais de ribossondas de hibridações in situ. A figura 4 mostra um esquema da seqüência de Hipk2 murina e os locais escolhidos para desenho das ribossondas. As regiões não possuem homologia com outros transcritos de camundongos, e uma delas (sonda ISO) já havia sido utilizada no trabalho de Pierantoni e colaboradores (2002). Além disso, as quatro ribossondas foram desenhadas de modo a não incluírem a região codificadora do domínio quinase, pois este é muito conservado entre as proteínas Hipks (KIM et al., 1998; revisto por CALZADO et al., 2007), o que poderia dificultar as análises de expressão.

Assim, quatro pares de iniciadores foram desenhados para amplificação de cada uma dessas regiões, a partir de cDNA de cérebro de camundongos de $17.5 \mathrm{dpc}$. O produto das amplificações foi clonado em pGEM-T Easy, e subclonado em pBluescript, um vetor que possui as regiões promotoras $\mathrm{T} 3$ e $\mathrm{T} 7$, a partir das quais foram transcritas as sondas de RNA senso e antisenso. A presença dos insertos de interesse e sua orientação no plasmídeo pBluescript foram confirmadas por digestão com enzimas de restrição e seqüenciamento. 


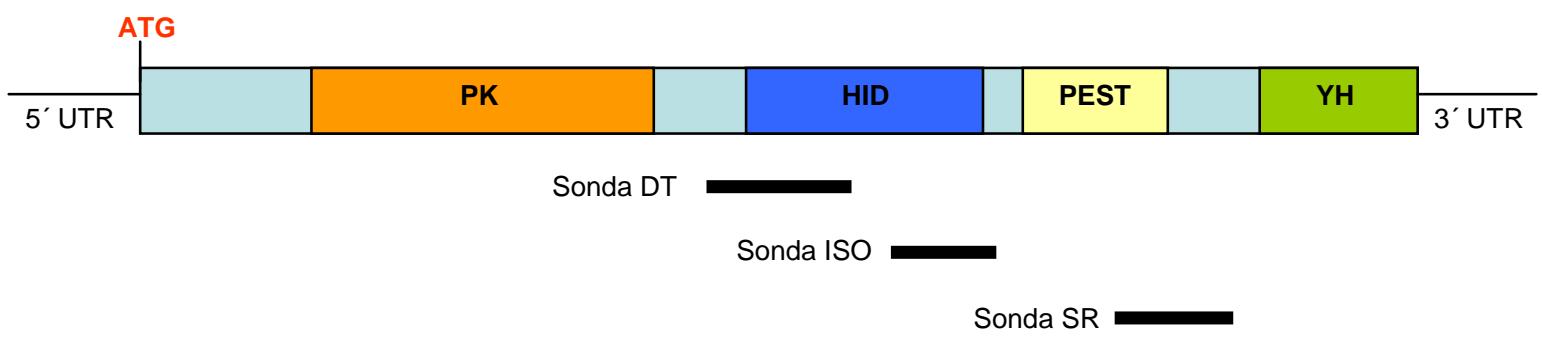

Sonda 3' UTR

Figura 4: Diagrama esquemático da seqüencia de cDNA de Hipk2 murina e a localização das regiões selecionadas para ribossondas nas hibridações in situ. PK: seqüência codificadora do domínio quinase; HID: seqüência codificadora do domínio de interação com homeoproteínas; PEST: seqüência que codifica domínio rico em prolina, ácido glutâmico, serina e treonina; YH: seqüência que codifica domínio rico em histidina e tirosina. Em vermelho, o códon iniciador ATG. As linhas pretas abaixo do diagrama representam a localização das ribossondas no transcrito de Hipk2.

4.1.2. Hibridação in situ em cortes histológicos de embriões de camundongos

Esta parte do trabalho foi realizada no laboratório de Genética e Cardiologia Molecular do Instituto do Coração (InCor-HC), sob co-orientação do Prof. Dr. José Xavier-Neto.

Inicialmente, as hibridações in situ foram feitas com cada uma das ribossondas para Hipk2 isoladamente, sempre utilizando como controle positivo uma ribossonda para o gene da Raldh2, cuja funcionalidade já havia sido testada pelo grupo do Prof. Dr. José XavierNeto (HochGreb et al., 2003). Como nenhuma das ribossondas para Hipk2 geraram sinal significativo quando utilizadas isoladamente, as quatro foram adicionadas em conjunto na solução de hibridação, o que resultou em distinta marcação, com background desprezível. Cortes de embriões expostos à sonda senso, controles negativos da hibridação, não apresentaram marcação. 
As figuras abaixo exibem o perfil de expressão de Hipk2 ao longo do desenvolvimento de camundongos obtidos por esta estratégia. Com 9.5dpc, é possível observar uma expressão ampla em diversos tecidos (Fig. 5).
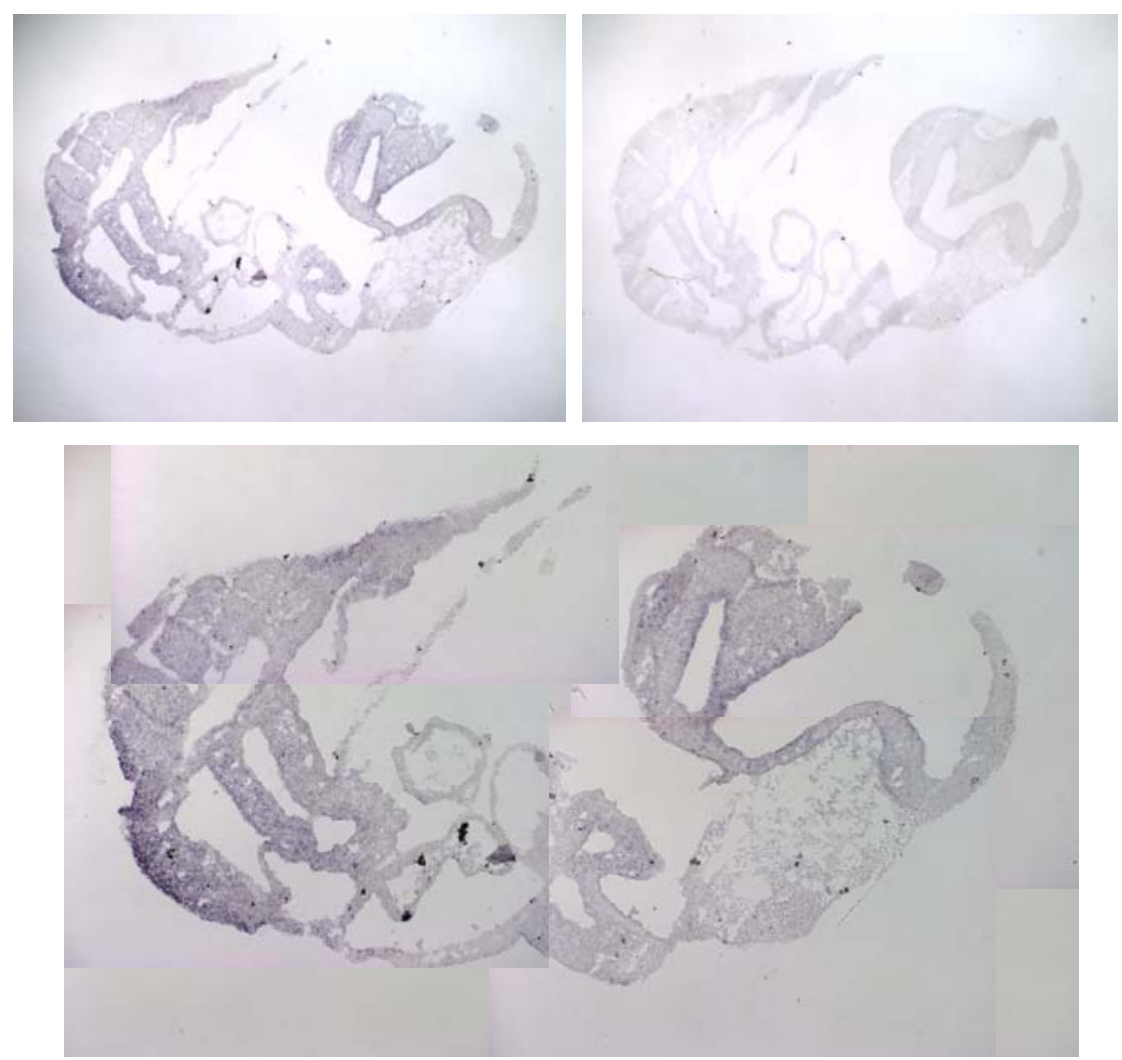

Figura 5: Expressão de Hipk2 em embrião de 9.5dpc. Acima, à esquerda, a ampla expressão de Hipk2 é observada no corte incubado com a sonda antisenso. Acima, à direita, embrião incubado com a sonda senso, utilizado como controle negativo da hibridação in situ. Abaixo, ampliação do embrião incubado com a sonda antisenso.

De forma geral, com 11.5dpc (Fig. 6) e 12.5dpc (Fig. 7), ainda pode-se observar uma ampla distribuição de Hipk2, com maior marcação no tubo neural, na zona ventricular 
do córtex cerebral em desenvolvimento, no músculo da língua e em gânglios nervosos dorsais.
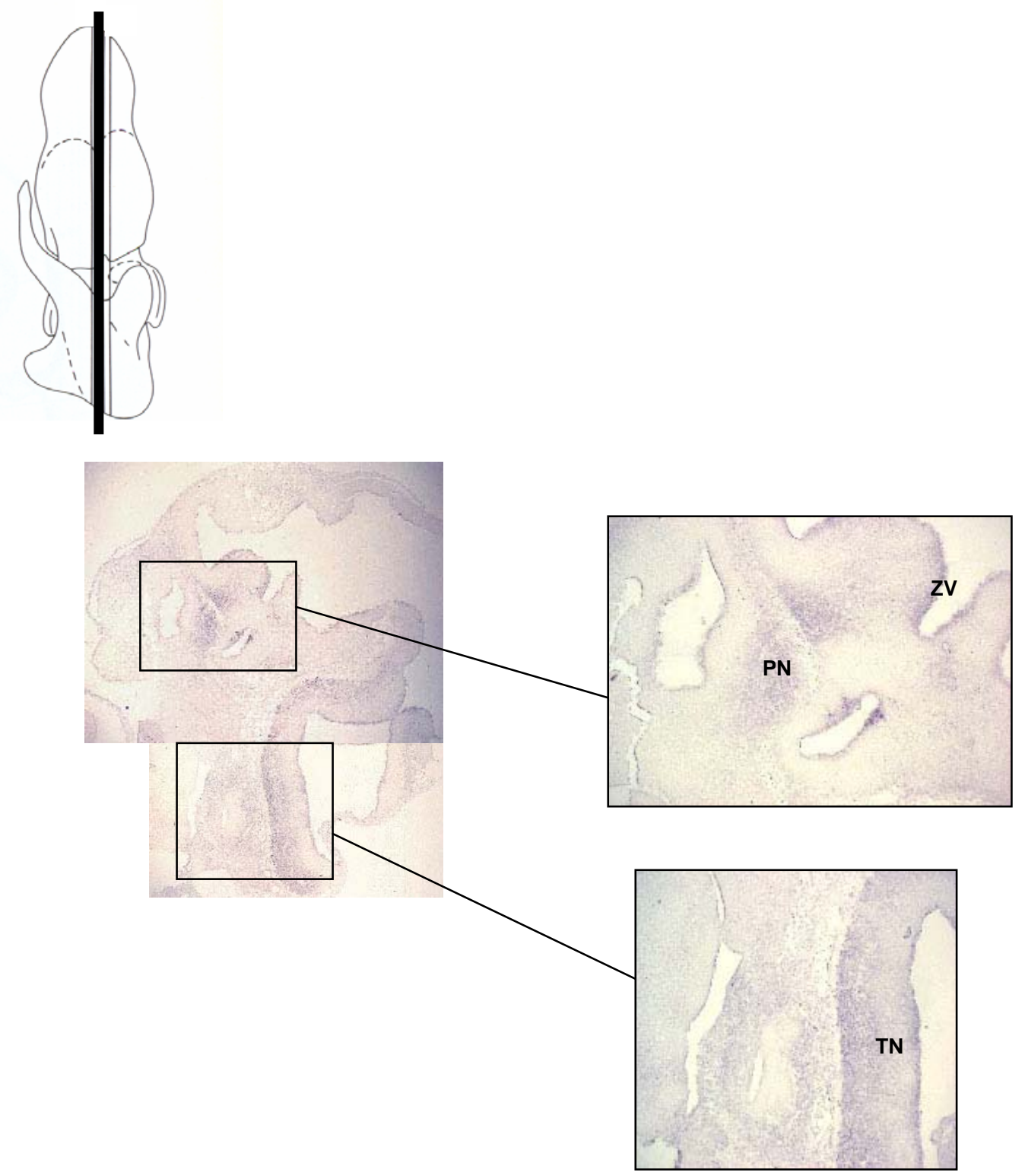

Figura 6: Expressão de Hipk2 em cortes sagitais de embriões de 11.5dpc. Acima, representação esquemática do corte realizado (retirado de KAUFMAN, 1992). Abaixo, à esquerda, vista da região cranial do embrião. À direita, em maior aumento, regiões onde detectou-se maior expressão de Hipk2. PN: primórdio de cartilagem do septo nasal; TN: tubo neural; $\mathrm{ZV}$ : zona ventricular do córtex. 


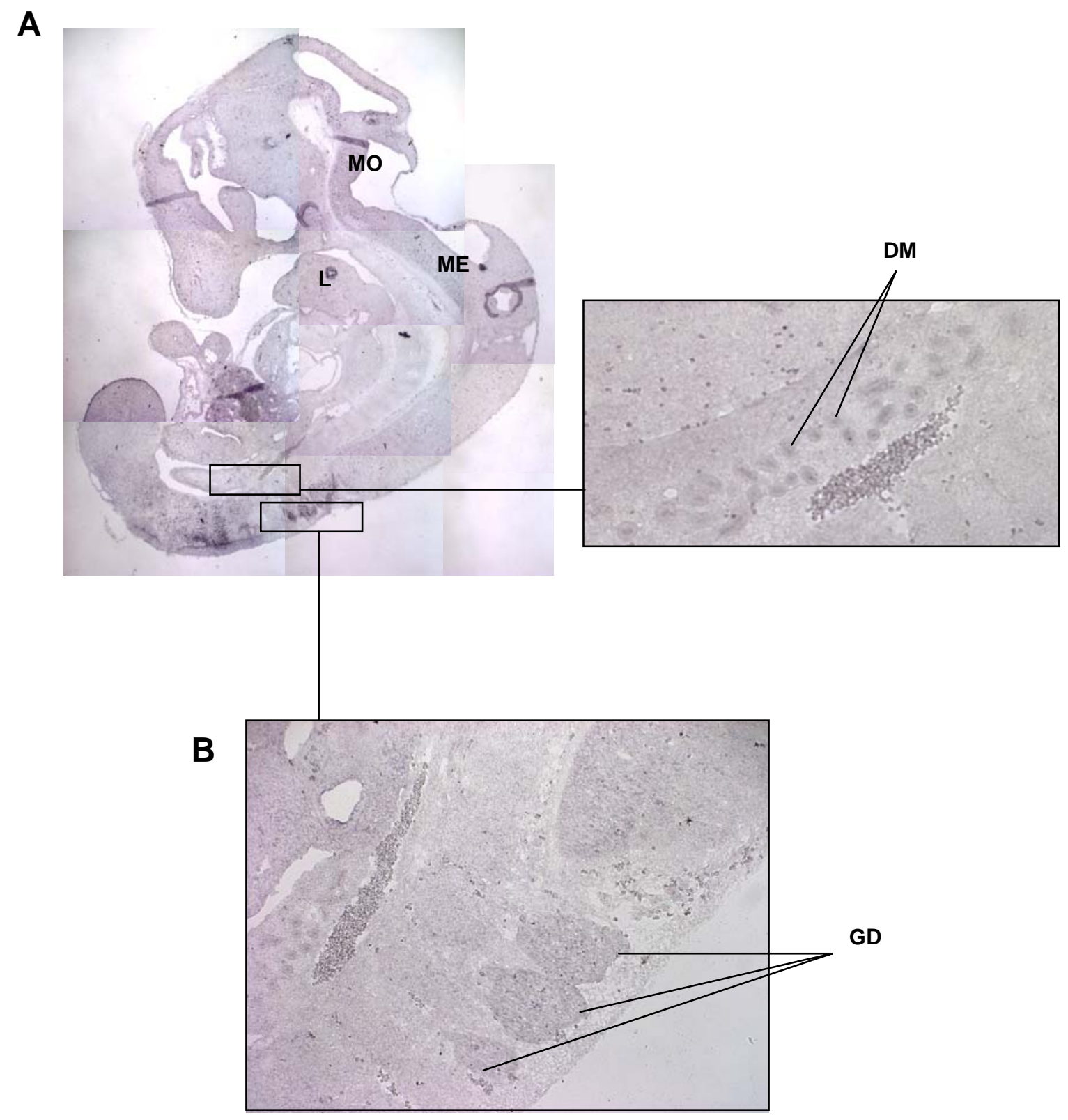

Figura 7: Expressão de Hipk2 em embriões de 12.5dpc. Em A, à esquerda, corte parassagital de embrião de $12.5 \mathrm{dpc}$, mostrando ampla expressão de Hipk2 (L: língua; MO: medula oblonga; ME: medula espinhal). À direita, detalhe de expressão de Hipk2 em dutos mesonéfricos (DM). Em B, o transcrito de Hipk2 é encontrado nos gânglios da raiz dorsal (GD). 
A expressão de Hipk2 no embrião entre o $13^{\circ}$ e o $14^{\circ}$ dia pós-coito não se altera (Fig. 8 e 9). Porém, cortes transversais da região cranial de embriões com 14. dpc foram submetidos à hibridação in situ, revelando regiões do sistema nervoso central em desenvolvimento com expressão diferencial de Hipk2, principalmente no gânglio trigeminal e vestibulococlear, na medula espinhal e no olho (Fig. 9C).

A

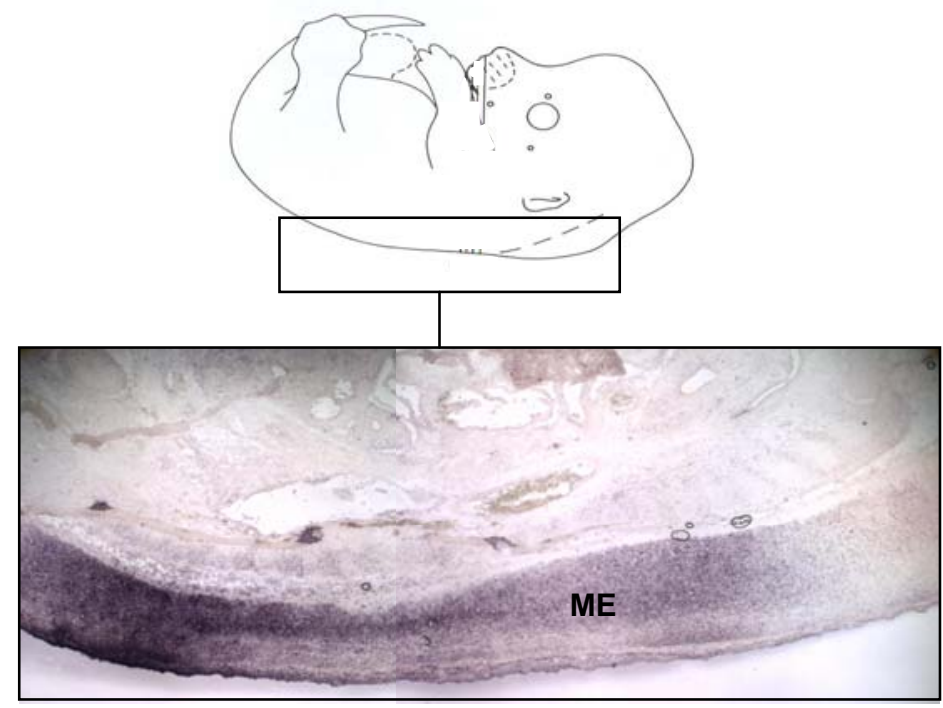

B

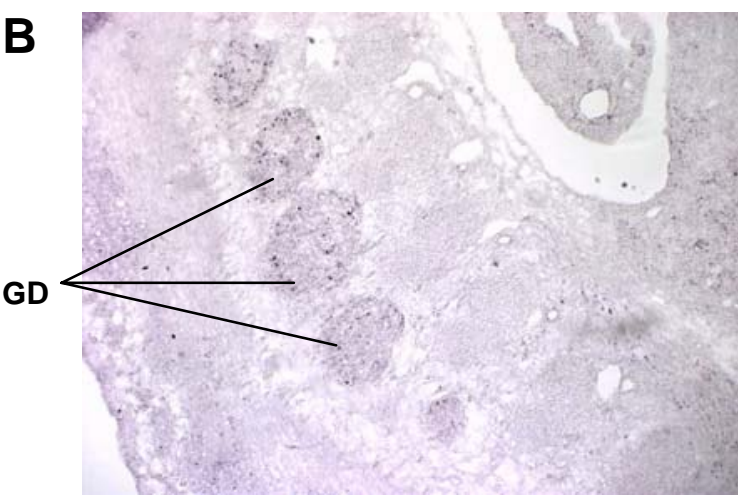

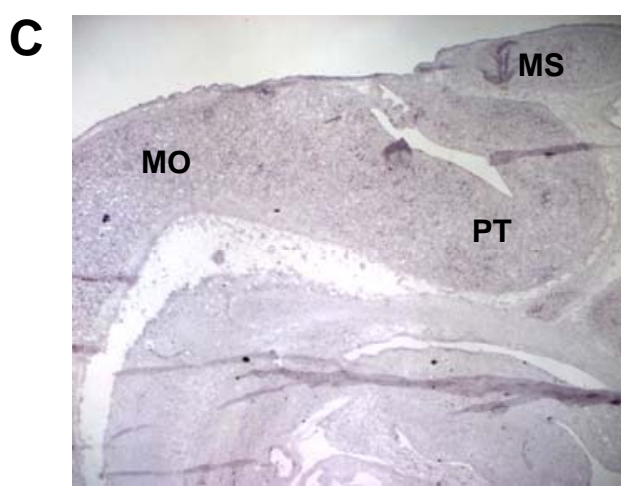

Figura 8: Expressão de Hipk2 em embriões de 13.5dpc. Em A, região dorsal do embrião (ver representação acima, retirado de KAUFMAN, 1992) mostrando expressão do gene na medula espinhal (ME). Em B, ampliação mostrando expressão de Hipk2 nos gânglios nervosos dorsais (GD). Em C, região cranial, onde a expressão de Hipk2 é observada no cérebro em desenvolvimento (MO: medula oblonga; MS: mesencéfalo; PT: ponte). 

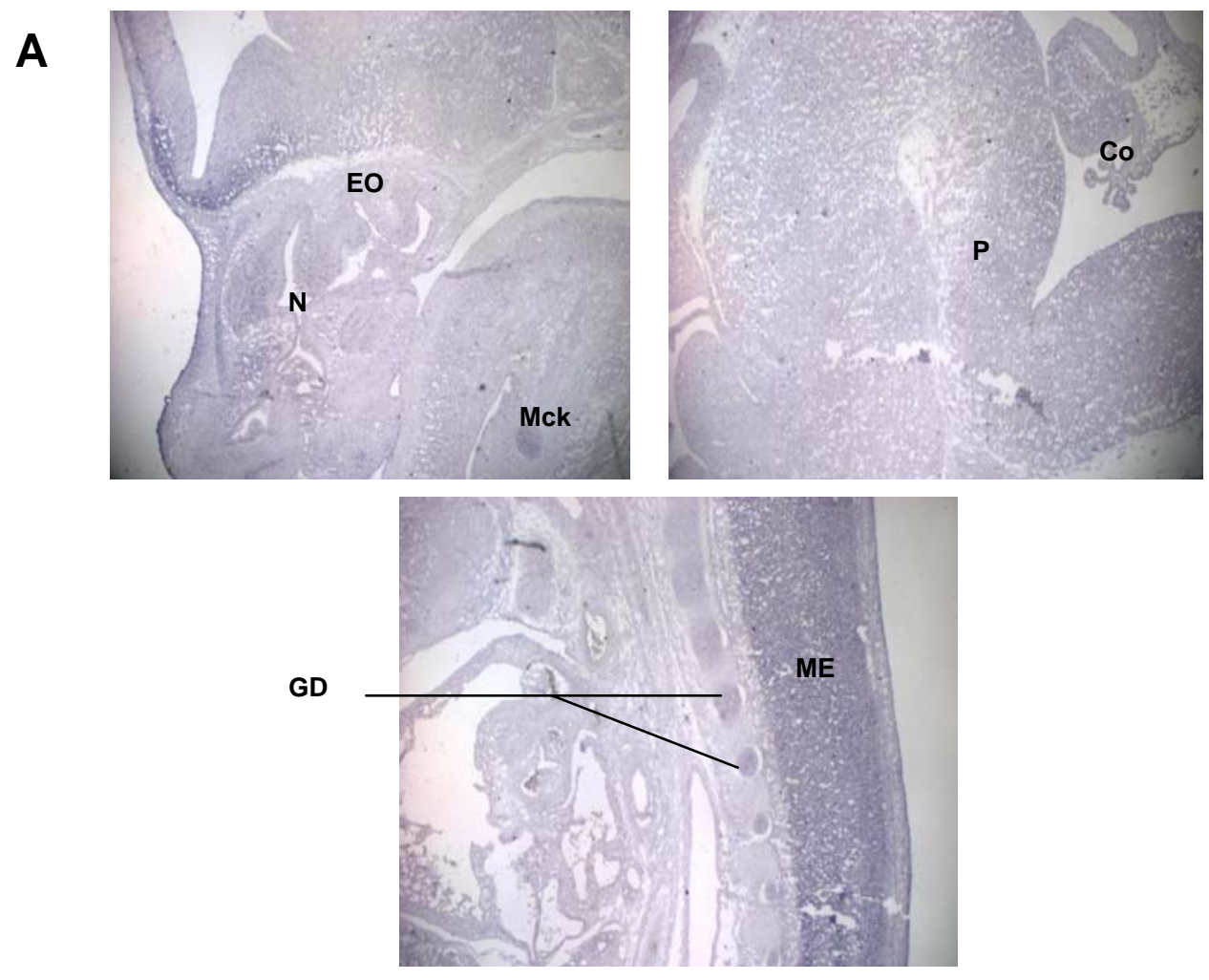

B
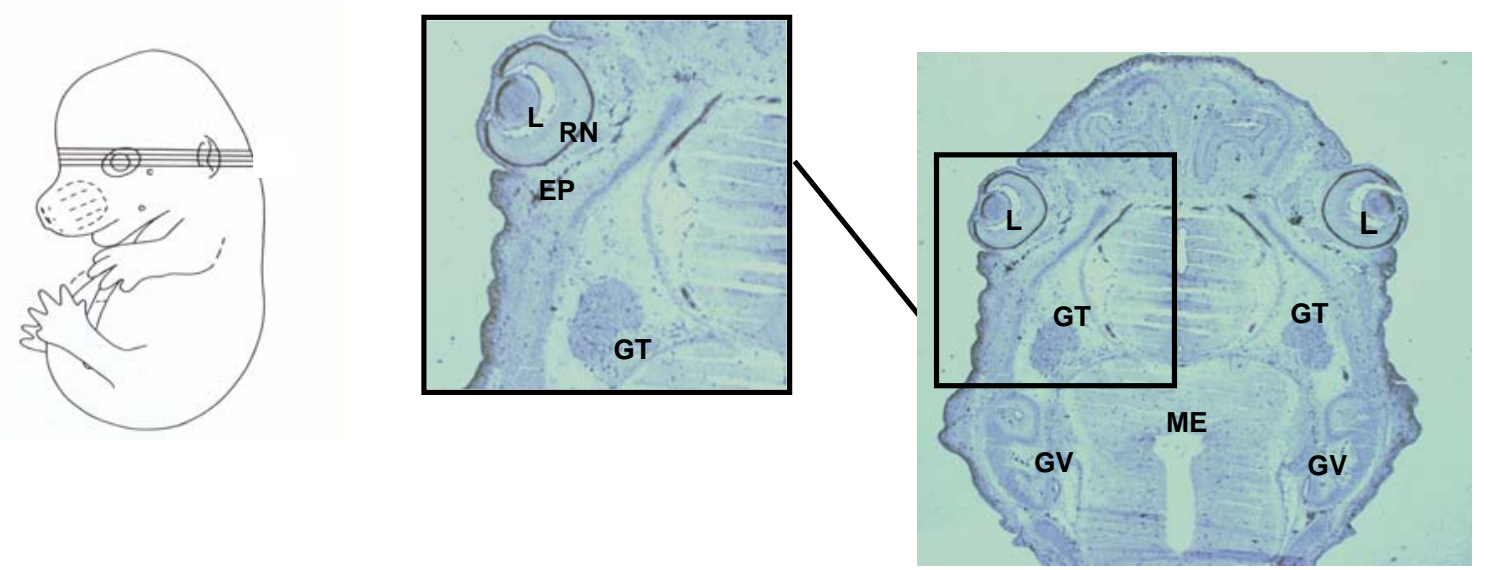

Figura 9: Perfil de expressão de Hipk2 em embriões de 14.5dpc. Em A, cortes parassagitais de embriões mostrando tecidos com maior expressão de Hipk2 (Co: plexo coróide; EO: epitélio olfativo; GD: gânglios nervosos dorsais; Mck: cartilagem de Merckel; ME: medula espinhal; N: cavidade nasal; P: ponte). Em B, à esquerda, representação dos cortes transversais da região cranial realizados (retirado de KAUFMAN, 1992). À direita, regiões com maior expressão de Hipk2. EP - epitélio pigmentar da retina; GT - gânglio trigeminal; GV - gânglio vestibulococlear; L - lente; ME: medula espinhal; $\mathrm{RN}$ - retina neural. 
A partir do $14.5 \mathrm{dpc}$, a expressão de Hipk2 passa a ser menos ubíqua, e em embriões de $15.5 \mathrm{dpc}$ e $17.5 \mathrm{dpc}$, ela se restringe a tecidos nervosos e epitélios de tecidos (Figs. 10 e $11)$.
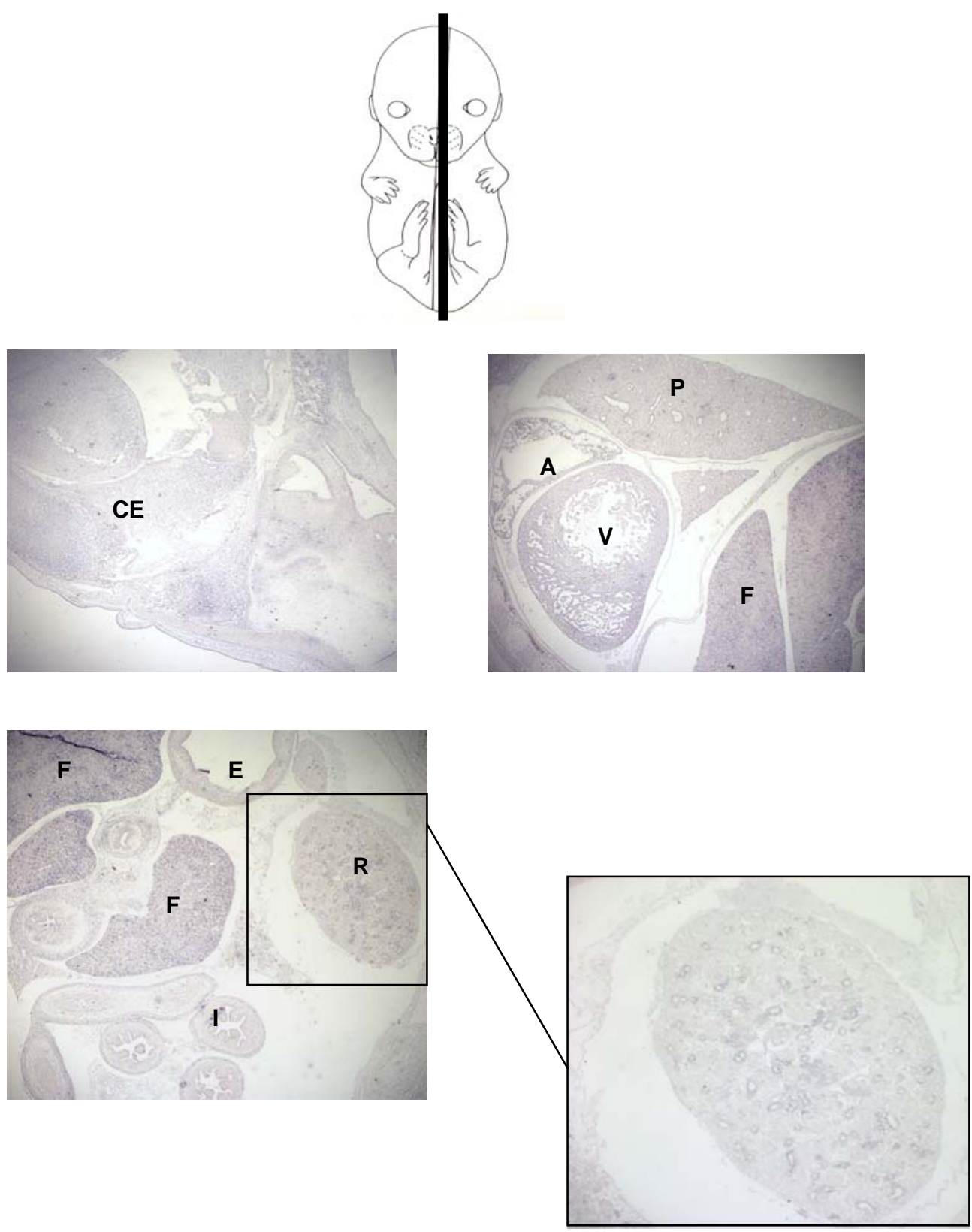

Figura 10: Expressão de Hipk2 por hibridação in situ em cortes parassagitais de embriões de 15.5dpc. Acima, representação do corte feito no embrião (retirado de KAUFMAN, 1992). O transcrito de Hipk2 é observado no córtex cerebral (CE), no ventrículo cardíaco (V), no fígado (F), nos epitélios do estômago (E) e do intestino (I) e no rim (R). À direita, em detalhe, a expressão de Hipk2 é observada nos dutos mesonéfricos renais. 


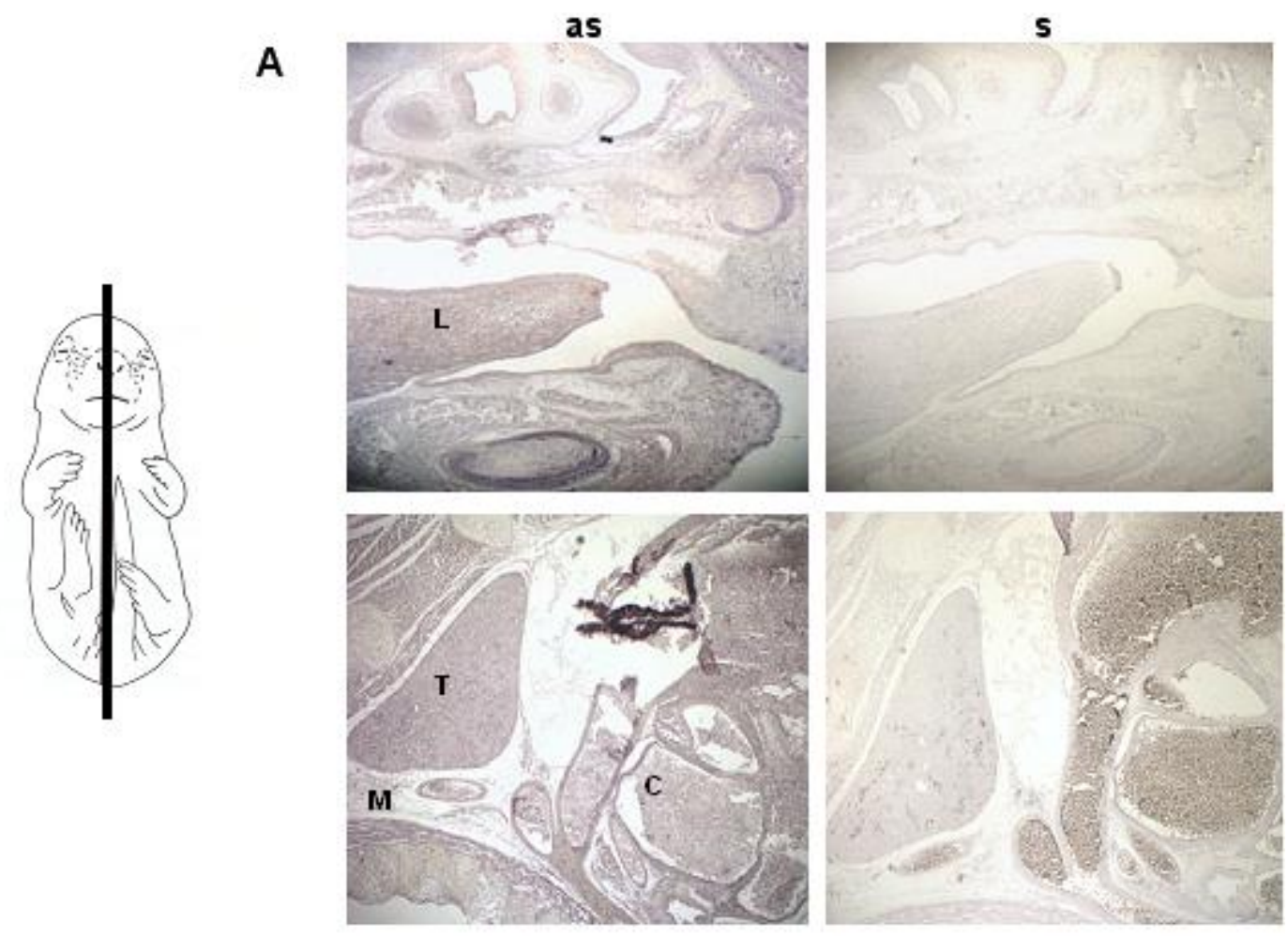

B

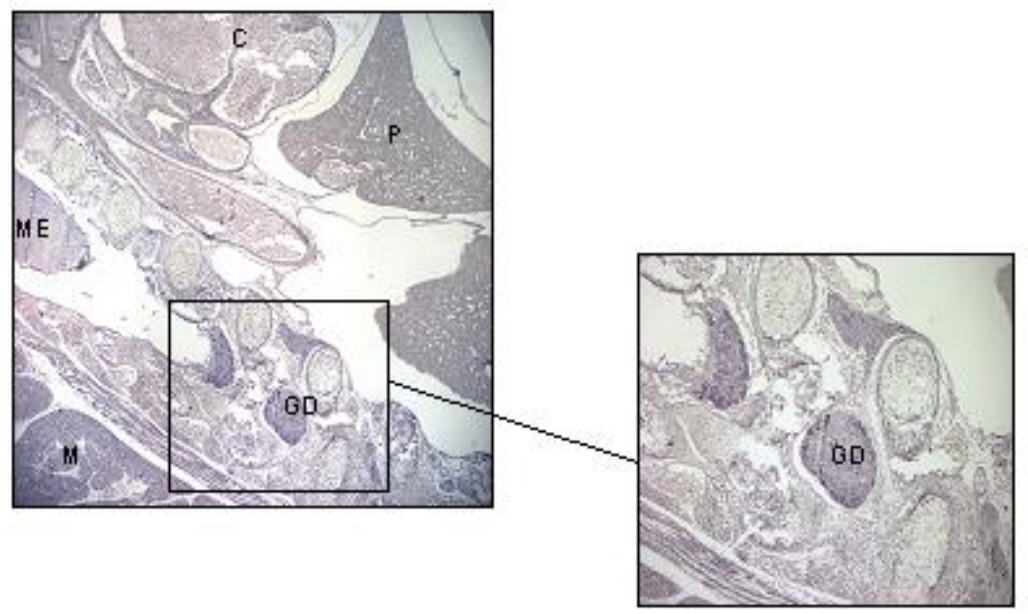

Figura 11: Expressão de Hipk2 em embriões de 17.5dpc. Em $\mathrm{A}$, à esquerda, cortes incubados com sonda antisenso (as). À direita, cortes incubados com sonda senso (s controle negativo). Em B, à direita, detalhe da marcação em gânglios dorsais (GD). C: coração; L: língua; M: músculo; ME: medula; P: pulmão; T: timo. O corte realizado está representado (retirado de KAUFMAN, 1992). 
A tabela 4 relaciona as etapas do desenvolvimento embrionário e os tecidos onde foi detectada maior expressão de Hipk2. Pode-se observar uma prevalência de expressão de Hipk2 em tecidos nervosos, desde os estágios mais precoces avaliados.

\begin{tabular}{|c|c|}
\hline $\begin{array}{c}\text { Estágio do } \\
\text { desenvolvimento } \\
\text { embrionário } \\
\text { (dias pós-coito - dpc) } \\
\end{array}$ & Expressão de Hipk2 \\
\hline 9.5 & Ampla expressão \\
\hline 11.5 & $\begin{array}{l}\text { Expressão ubíqua } \\
\text { Tubo neural } \\
\text { Zona ventricular do córtex } \\
\text { Primórdio de cartilagem nasal }\end{array}$ \\
\hline 12.5 & $\begin{array}{l}\text { Expressão ubíqua } \\
\text { Tubo neural } \\
\text { Gânglios nervosos dorsais } \\
\text { Dutos mesonéfricos }\end{array}$ \\
\hline 13.5 & $\begin{array}{l}\text { Expressão ubíqua } \\
\text { Cérebro e medula espinhal } \\
\text { Gânglios nervosos dorsais }\end{array}$ \\
\hline 14.5 & $\begin{array}{l}\text { Expressão ubíqua } \\
\text { Cérebro e medula espinhal } \\
\text { Gânglio trigeminal e vestibulococlear } \\
\text { Epitélio olfativo } \\
\text { Olho (lente, retina neural) } \\
\text { Cartilagem de Merckel } \\
\text { Língua }\end{array}$ \\
\hline 15.5 & $\begin{array}{l}\text { Cérebro } \\
\text { Rim (dutos mesonéfricos) } \\
\text { Fígado } \\
\text { Epitélio intestinal e estomacal }\end{array}$ \\
\hline 17.5 & $\begin{array}{l}\text { Cérebro e medula espinhal } \\
\text { Gânglios nervosos dorsais } \\
\text { Ventrículo cardíaco } \\
\text { Músculos } \\
\text { Timo } \\
\text { Pulmão } \\
\end{array}$ \\
\hline
\end{tabular}

Tabela 4: Expressão de Hipk2 ao longo do desenvolvimento embrionário de camundongos. A presença do transcrito de Hipk2 foi avaliada por hibridação in situ em cortes histológicos de embriões. 


\subsection{Regulação por HIPK2 da expressão de genes homeobox e HIPKs}

4.2.1. Construção dos vetores para silenciamento de HIPK2

Segundo Naito e colaboradores (2004), para maior eficiência do siRNA em mamíferos, alguns critérios devem ser obedecidos: ausência de repetição das bases C e G em mais de 9pb; presença de A ou U na extremidade 5'da fita antisenso; enriquecimento das bases A e U na extremidade 5' antisenso; e presença na extremidade 5' senso das bases G ou C (Fig. 12A). No total, três regiões do transcrito de HIPK2 foram selecionadas como alvo para o silenciamento: duas seqüências foram escolhidas pelos programas disponíveis na rede e uma terceira utilizada com sucesso por Di Stefano e colaboradores (2004). É interessante notar que não houve consenso entre as seqüências obtidas pelos programas. A figura 12B mostra as seqüências-alvo de 19nt para silenciamento de HIPK2 humana. A partir destas seqüências, foram desenhados e sintetizados três pares de oligonucleotídeos (OLIGO 3, OLIGO 4 e OLIGO S, Tab. 2).

A

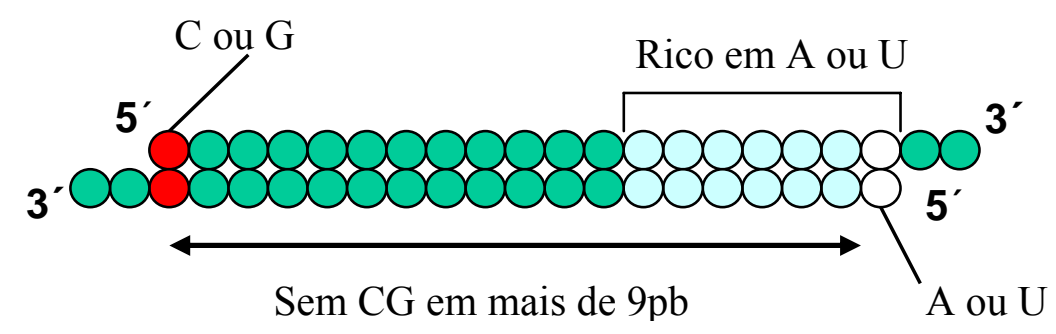


B

1

61

121

181

241

301

361

421

481

541

601

661

721

781

841

901

961

1021

1081

1141

1201

1261

1321

1381

1441

1501

1561

1621

1681

1741

1801

1861

1921

1981

2041

2101

2161

2221

2281

2341

2401

2461

2521

2581

2641

2701

2761 ttacagggcc ctgggctgt gttattgcag gtatgatcag attcggtata cgccgggaca aagacaacta gagactgaag acaccagatg agggagcgac gatgctgacc tgtcaccatg gaacatggag ccctttcatc ccagctgacc caatccogaa catggctgca coggcctgac ggcctctccc cactcaagcc ttggccaagt ggcсасссас gcagctggcg gcagcctgca tgtggcссас gcaccagtca ctccccacag cagtagcccg caccogggaa cgtcatcacc cactgtctcc ctccgactcc tgccaatgcc catcatcgtg ggtgccagtc gacctccacc gcggccgggc catcaccacg ggcccaggct tctggctgca tgcgceggcg tgcgcgccac gagcatgggc atttgcccac actgagcccc agggagggag gaccgtgggc ggggcggggg accgggaagt gagggtggga ttcaactgtt

atgttggtag

attgatgctg

acacacttac atctgcaagc acgcacgtgg gtctccatac gtggcccagc ccgttccagc tctaagcacg ccaggagctc gggacccagc acatcagtgc gactggagaa ctattgaccg gtgatgcggc tctgtgagaa cgatccaagc gcctgcagca cggcagcggc atcagcagtg aagcaaagaa tccagcaaca ccacccctga aacaccagtc agcggtcact ccccacttcc gaccgcactg ccgtactcct gccgctgcog gccetgggct accgtgcagc ccccgggtcc cagacctaca gccaaggtca ggagagaatg gctggcctt gggggggggc gggaggacgt aatctatggt actgtccaca tttgacacca tccttggtt aattgttcct tt cacaaac ggttttcaa accatgaagc tagatgatat aaaaggctga acaagagaat tcgattttcc gtcgggtgaa cccccagcac accaggctcc taaactaccc ggagcatgcc aagctctcat ctggctactc agcctcttca agatcctgct agcatgccac atacgcatgc gtcatgtgac agcagccaac atgtctccac gtgtcaagga cctcggtcac agacaattgt acacggacga aaaacgtcat ccagccccta aggggagcct aaacccaggc accactcgtc cttcagggag agcagcagca ggagccaccg tcccgcacaa ctgcccacct ccaccggcac acactgccta tgccetcgcc tcagcgcctc accagtaccc gcccgaggga tatactgaag agagggcagg agagcagaga tttattta accattttgt gggttggccg acagggtttg ccgtgacacg agagacaggg ggcccaggtg ccggcgggag cactccaatc ccacagcaca tatgtatgac gtccaccaac ctcctctacc atctacactc cctgcagaca cgtgtgtccc ggtgcgaatg gatccaacca tcccccagca cgtgattccc tcacggaagc ccttccagca cagcaccacc ctgtgaggtg gaacacacct ctgtgggtgg cattcccgac ggaggaggaa cagctgtgtc ctccgtgcag ggagaatcac cagcgaagta ctcctacaag ctcatctgga gccactcaat aaggcagcag cagccccagc ccccacccag cgtggcccac cccagccagc caccatccac gccagcctcc ttacatataa ggagggagag atgccgcaca gggacgggtc agagaacatt aaaaaaaaaa gaggcaattg acatgtggtc ttatatccag gagcttcgga cctgctgaat atttattaag gactcaccat atcctttgtg attaagtcaa aacatgacga ttcattgacc gaaaccctga cacgtcaaat acggtgaacc ctgaccatga agtgccacta taccagccct ggaacagccc cccggcttcc gaaaatgcag ggtctgcttg tggcagcaac gagaccatgg cattataatc gcacagccet tcctcccgga tcctcotctc cccogctgtg ggcgacgtgg actcccagcc cagaaacacg acagtccacg cagcgtgctg tgcacgggga ttggtggagt tccaagtcct gccatcacct ctcagccagg gcctacatca cacggcactg ccccacctct ctggtggcct atcgtccacc ccgagtcagt accgtctaca acactggagg aaggagggag caaacaatgc gggacaccag tttaaaagga $a$

tgttgaagaa

accatccctt

catgtttcca

agagcaaaac

aagaagcaag siRNA3

cagatttgga siRNAS 


\subsubsection{Análise da funcionalidade dos shRNAs}

Cada par de oligonucleotídeos foi anelado e clonado em pSuper (BRUMMELKAMP et al., 2002), um vetor de expressão de shRNA comumente empregado em mamíferos. Após 60 minipreps de cada construção, foram obtidos 2 clones da construção pSuper+oligo3 (pS3), 4 clones da construção pSuper+oligo4 (pS4) e 1 clone pSuper+oligoS (pSS), indicando uma baixa eficiência de clonagem. Contudo, o seqüenciamento destes clones confirmou sua integridade.

Células 293 EBNA foram co-transfectadas com cada vetor de shRNA e pBabe, este último para seleção com puromicina. O vetor $p$ Super original (sem inserto) foi utilizado como controle negativo. Após dez dias de seleção com puromicina, colônias resistentes foram isoladas de cada construção, e a presença do respectivo vetor de expressão de shRNA confirmada por PCR a partir de DNA genômico das mesmas (Fig. 13). Cerca de $40 \%$ a $70 \%$ das colônias resistentes a puromicina continham o vetor de expressão de shRNA.

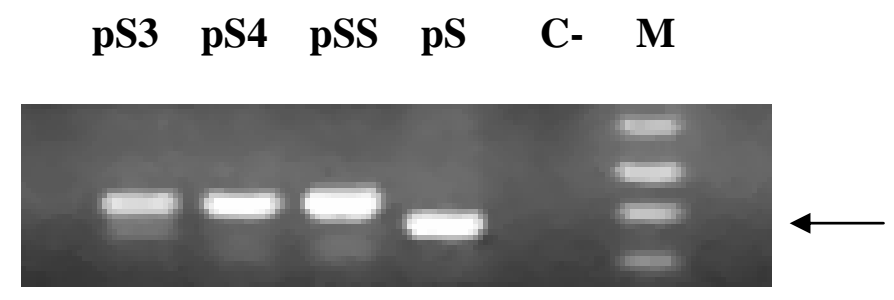

Figura 13: PCR para confirmação da presença do vetor pSuper nas células transfectadas. pS3, pS4 e pSS correspondem a células transfectadas com pS3, pS4 e pSS, respectivamente. $\mathrm{pS}$ refere-se a células transfectadas com o vetor original pSuper. C-: controle negativo sem DNA; M: marcador de peso molecular (1Kb ladder, Invitrogen). A seta indica o tamanho de $300 \mathrm{pb}$. 
Para avaliar a expressão de HIPK2 por RT-PCR nestas células, foi feita a padronização do número mínimo de ciclos onde fosse possível visualizar o nível do transcrito de HIPK2 sem saturar a reação (RT-PCR semi-quantitativa), utilizando-se GAPDH como gene normalizador da quantidade de cDNA das amostras (dados não mostrados). Definidos o número de ciclos (29 para HIPK2 e 19 para GAPDH), foi realizada a RT-PCR semi-quantitativa das células transfectadas com as construções pS, pS3, pS4 e pSS (Fig. 14). Os iniciadores de HIPK2 utilizados amplificam dois fragmentos, que se referem as duas isoformas de HIPK2 originadas por splicing alternativo (STUKART, 2001).

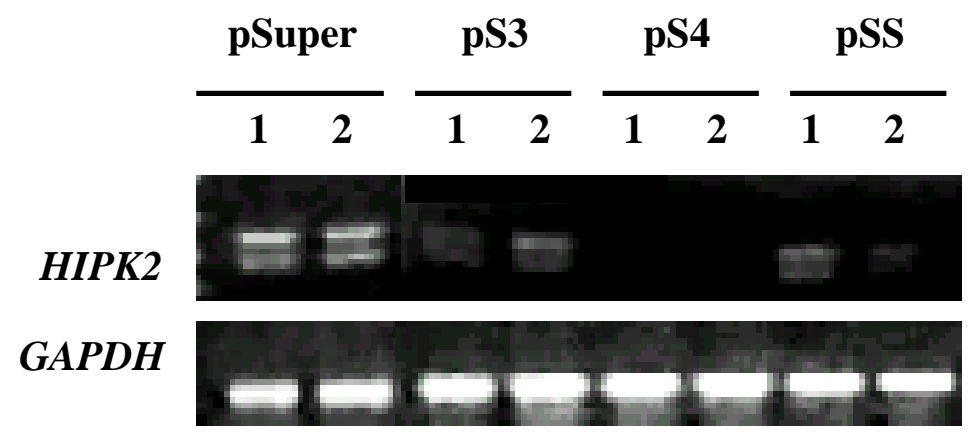

Figura 14: Expressão de HIPK2 em clones transfectados com vetores para silenciamento do gene por RT-PCR semi-quantitativa. Os respectivos vetores estão indicados acima de cada amostra. Os números 1 e 2 correspondem a dois clones de cada construção. GAPDH foi utilizado com normalizador.

Foi possível observar com clareza uma menor expressão do transcrito de HIPK2 nos dois clones transfectados com o vetor pS4, indicando a eficácia desta construção na inativação de HIPK2. Embora não quantificada, pode-se verificar também diminuição de expressão de HIPK2 nos clones obtidos após transfecção com as construções pS3 e pSS. 
Para uma avaliação quantitativa definitiva da expressão de HIPK2 após transfecção com vetores de silenciamento gênico, foram realizadas RT-PCRs em tempo real. A figura 15 mostra um gráfico de quantificação da expressão de HIPK2, tendo como normalizador o gene constitutivo GAPDH. Como não foi observada variação nos níveis dos transcritos de HIPK2 entre os clones transfectados com pSuper por RT-PCR semi-quantitativa, utilizouse como calibradora das reações de RT-PCR em tempo real uma amostra denominada pSpool, contendo cDNA dos diferentes clones resultantes da transfecção com o vetor pSuper original.

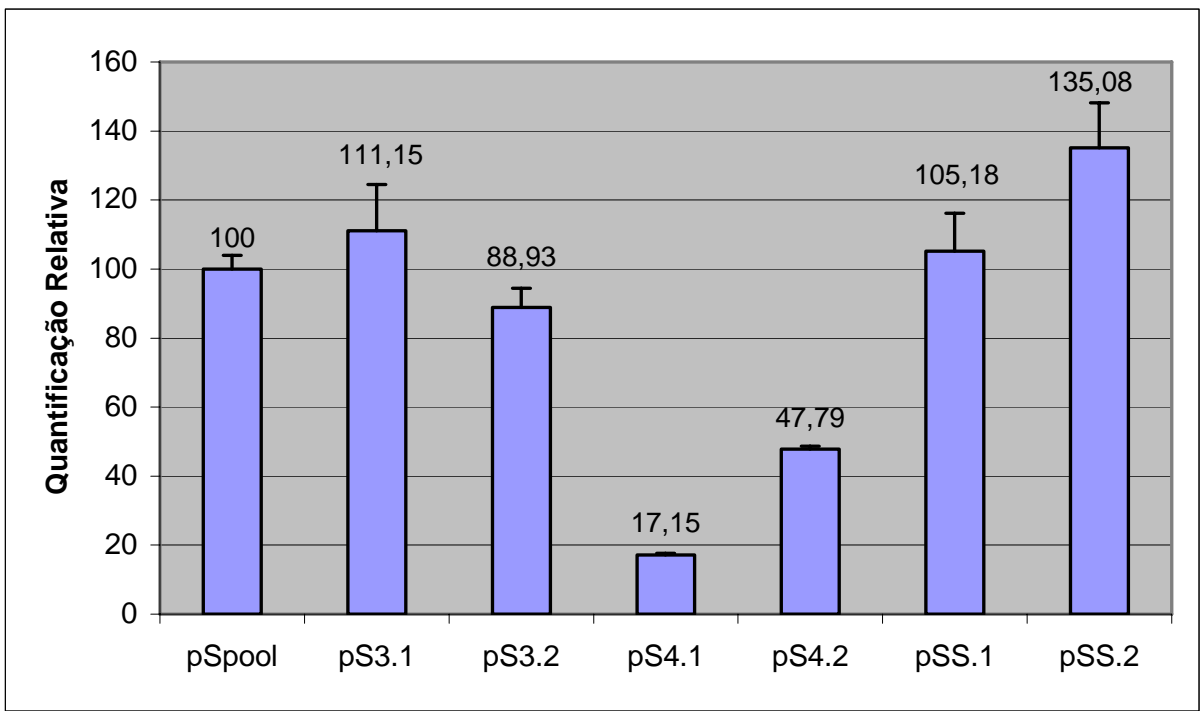

Figura 15: Quantificação da expressão de HIPK2 em clones transfectados com vetores para silenciamento do gene por RT-PCR em tempo real. GAPDH foi usado com gene normalizador. A amostra calibradora da expressão dos genes foi denominada pSpool, e refere-se a um conjunto de quatro clones resultantes da transfecção com o vetor $p S u p e r$ original. A expressão de dois clones de cada construção (pS3, pS4 e pSS) foi avaliada. Os experimentos foram feitos em triplicatas. As barras representam o erro padrão.

Alguns trabalhos apontam para possíveis erros decorrentes do uso de um único gene como normalizador nas RT-PCRs em tempo real (VANDESOMPELE et al., 2002; 
ZHANG et al., 2005; DE KOK et al., 2005). Assim, dois outros genes foram utilizados como normalizadores nas reações de RT-PCR em tempo real, HMBS e HPRT1. A figura 16 mostra os resultados destas reações feitas com os outros genes normalizadores, além de um gráfico com a média dos perfis de expressão de HIPK2 entre os três genes endógenos testados.

A

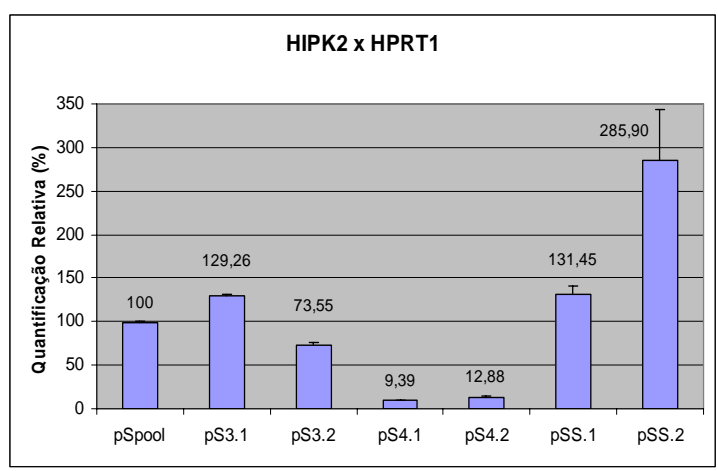

B

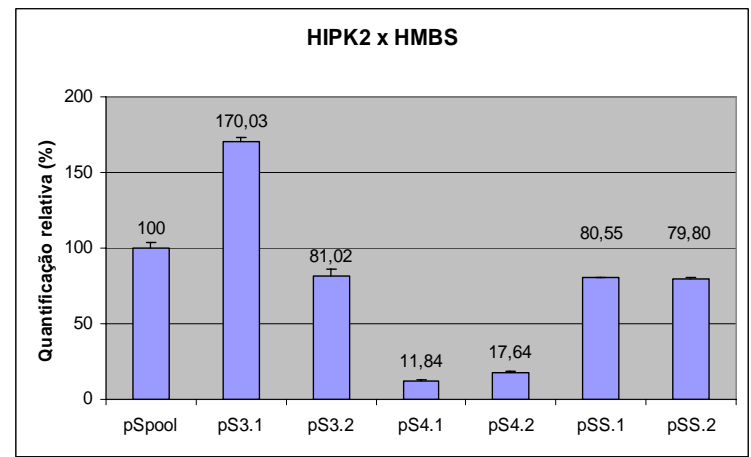

C

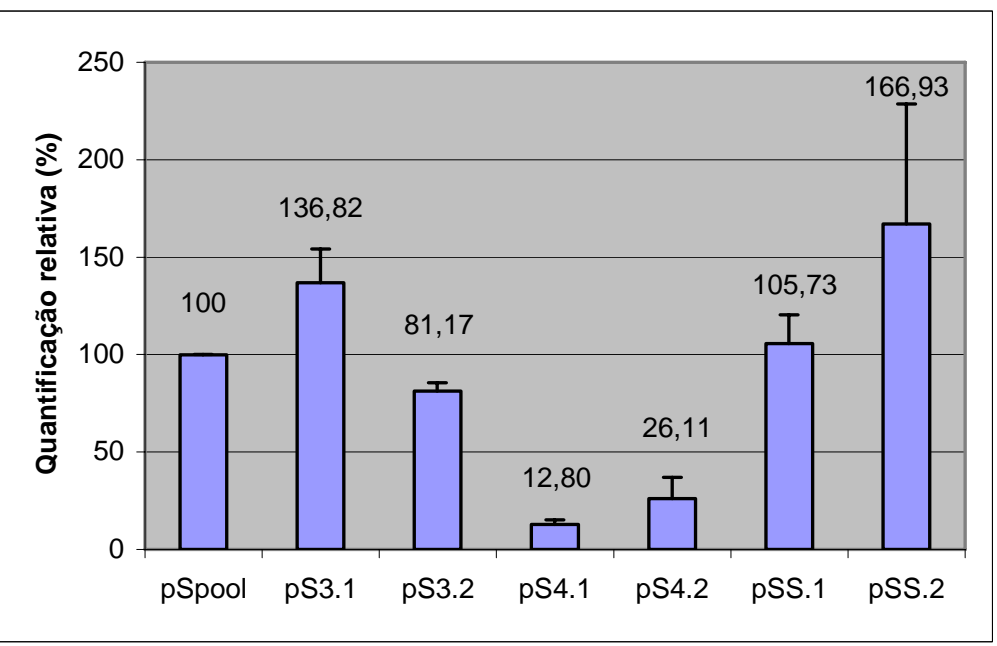

Figura 16: Expressão de HIPK2 em clones transfectados com vetores para silenciamento do gene por RT-PCR em tempo real, em relação a diferentes controles endógenos. Em A, o gene normalizador usado foi HPRT1, e em B, HMBS. Em C, gráfico composto pela média dos valores obtidos para os três genes normalizadores (GAPDH, HPRT1 e HMBS). As barras representam o erro padrão. 
Os resultados das RT-PCR em tempo real confirmaram que o vetor mais eficiente para inativação de HIPK2 endógeno foi pS4. Independente do gene usado como controle endógeno, os dois clones obtidos após transfecção com pS4 tiveram menor expressão de HIPK2, se comparados com a amostra calibradora ( $p S p o o l)$. Este vetor foi utilizado nos experimentos seguintes de inativação de HIPK2.

A figura 17 mostra o resultado de uma RT-PCR em tempo real de outros clones obtidos da transfecção com o vetor $\mathrm{pS} 4$, usando como normalizadores os genes HPRT1 $e$ GAPDH.

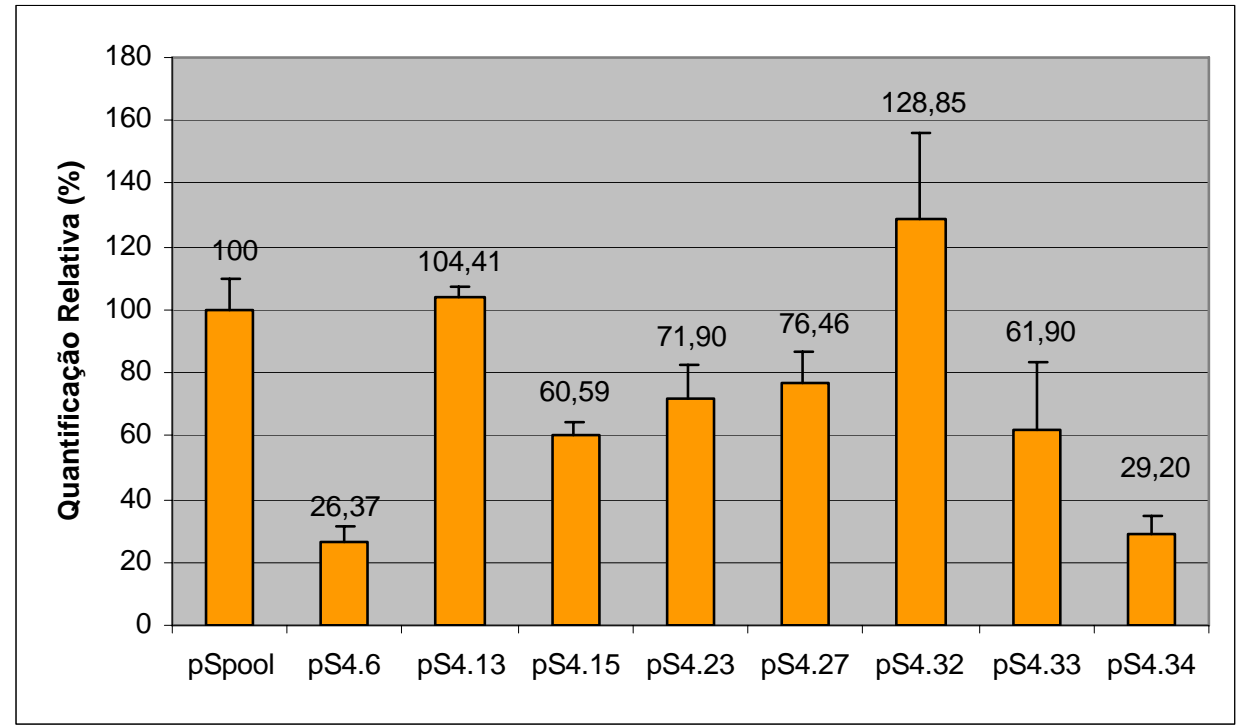

Figura 17: Análise por RT-PCR em tempo real da expressão de HIPK2 em diferentes clones transfectados com $p S 4$. Os resultados representam a média das quantificações utilizando HPRT1 e GAPDH como normalizadores e a amostra pSuper como calibradora das quantificações. Os experimentos foram realizados em triplicatas. As barras representam o erro padrão.

Em seis dos oito clones analisados houve diminuição na expressão de HIPK2, comprovando a eficiência do vetor pS4. Os clones pS4.1, pS4.2, pS4.6, pS4.33 e pS4.34 
foram utilizados para avaliação do efeito do silenciamento de HIPK2 na expressão de genes homeobox e HIPKs.

4.2.3. Efeito da inativação de HIPK2 na expressão de genes homeobox $e$ HIPKs

Clones transfectados com o vetor de silenciamento $\mathrm{pS} 4$ foram avaliados quanto à expressão dos genes HIPK1 e HIPK3, e dos genes homeobox NKX2.5, NKX3.1, NKX6.1 e PAX6.

A expressão destes genes foi analisada por RT-PCR em tempo real (Figs. 18 e 19). Optou-se por agrupar as células silenciadas (pS4.1, pS4.2, pS4.6, pS4.33 e pS4.34) em amostras únicas (pool de células), com o objetivo de se eliminar variações individuais dos clones.

A figura 18 mostra o gráfico de quantificação de expressão dos genes HIPK1, HIPK2 e HIPK3. A diminuição de $71 \%$ no nível do transcrito de HIPK2 provocou aumento considerável na expressão de HIPK1 (114\%), e em menor grau também em HIPK3 (43\%). 


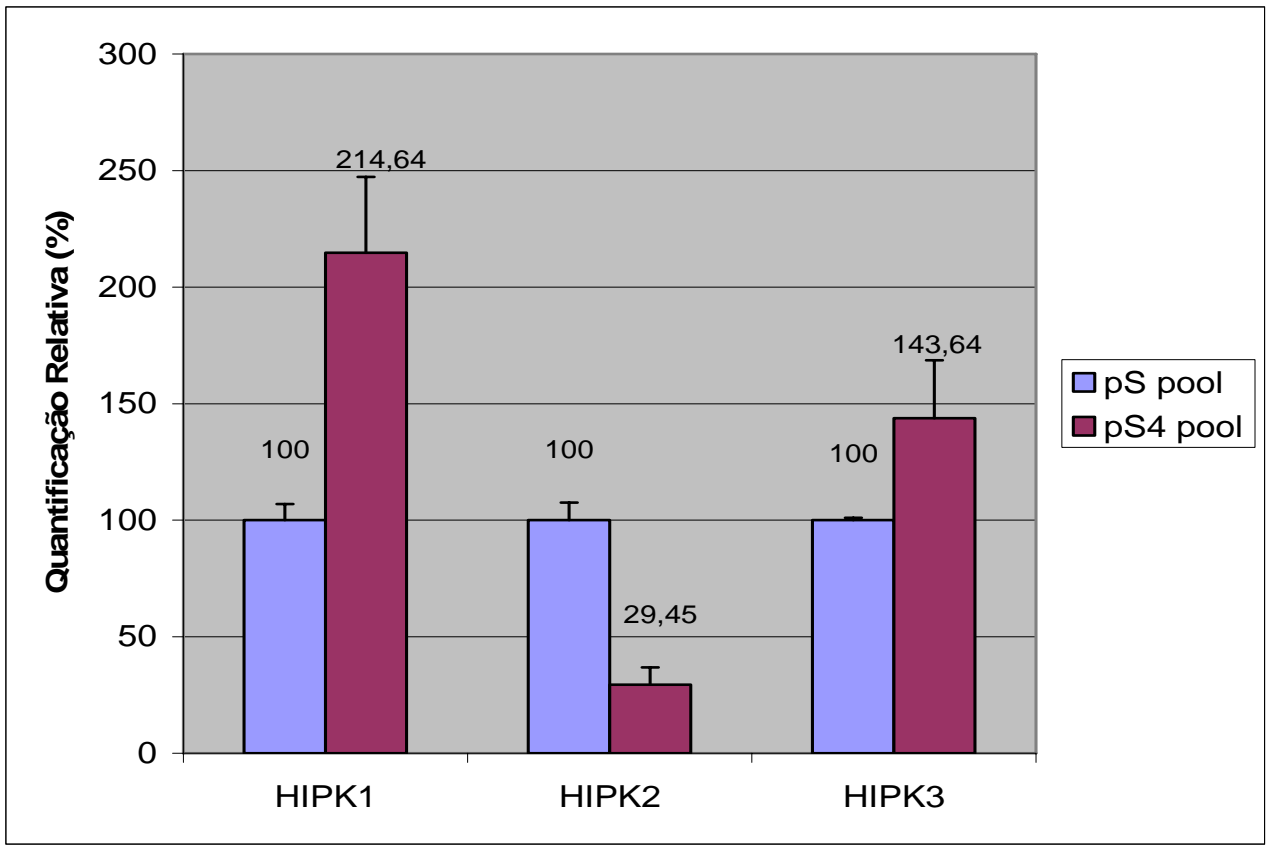

Figura 18: Efeito do silenciamento de HIPK2 nos níveis de expressão dos genes HIPKs. Os resultados representam a média das quantificações utilizando HPRT1, HMBS e GAPDH como normalizadores e a amostra pSuper como calibradora das quantificações. Os experimentos foram realizados em triplicatas. As barras representam o erro padrão.

A figura 19 mostra a expressão dos genes $N K X 2.5, N K X 3.1, N K X 6.1$ e PAX6, após silenciamento de HIPK2 por shRNA. Pode-se observar aumento do nível de expressão de NKX3.1 e NKX6.1 e PAX6 (85\%, 44\% e 29\%, respectivamente). Não foram observadas mudanças nos níveis de expressão de NKX2.5. 


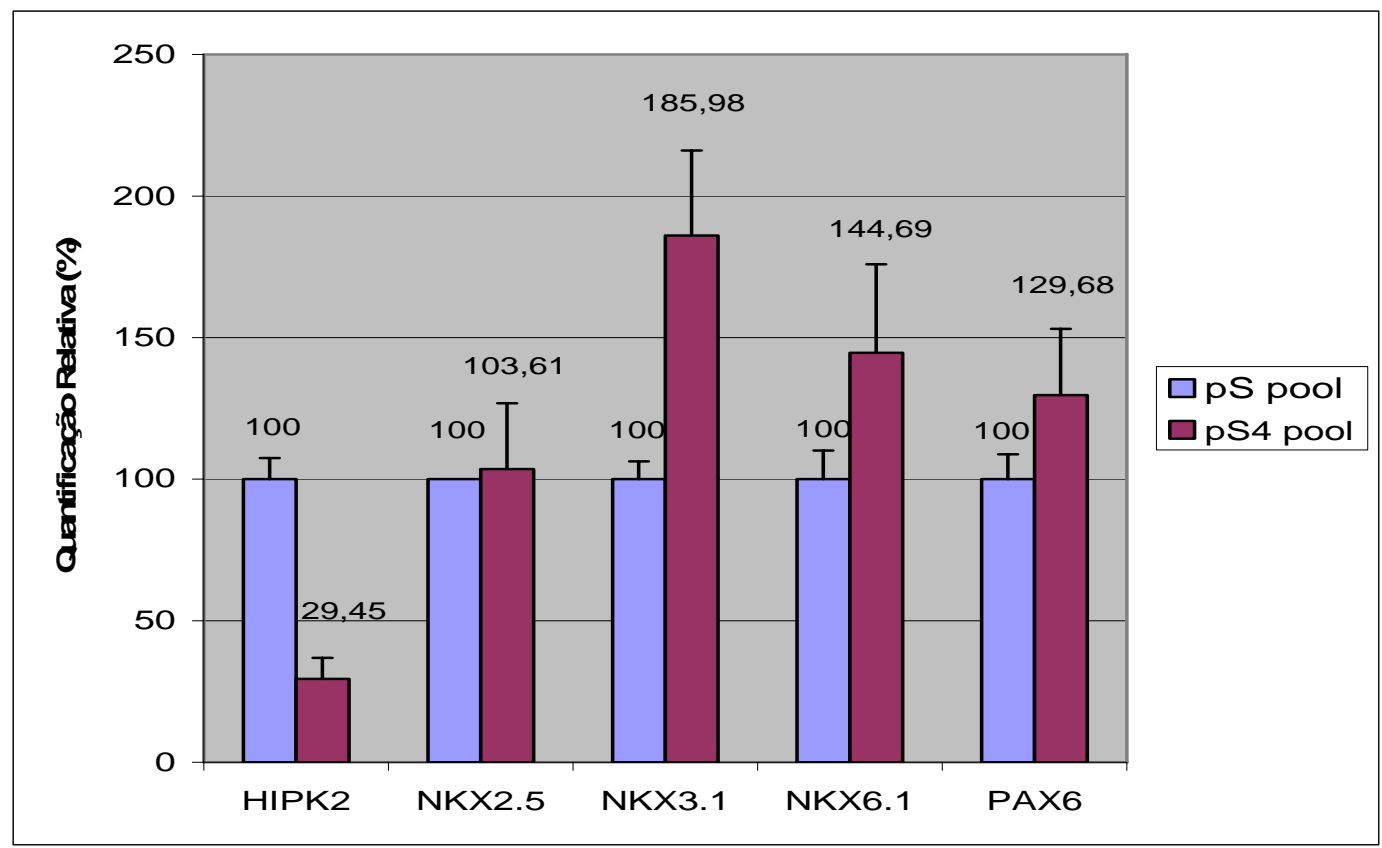

Figura 19: Efeito do silenciamento de HIPK2 nos níveis de expressão de genes homeobox. Os resultados representam a média das quantificações utilizando HPRT1 e GAPDH como normalizadores e a amostra pSuper como calibradora das quantificações. Os experimentos foram realizados em triplicatas. As barras representam o erro padrão. 


\subsection{Perfil de expressão de Hipk2 durante o desenvolvimento embrionário de camundongos}

O objetivo deste trabalho foi inferir possíveis funções do gene Hipk2 na embriogênese, avaliando seu perfil de expressão temporal e espacial durante o desenvolvimento de camundongos por hibridação in situ, uma ferramenta poderosa para este tipo de investigação.

A figura 20 resume o perfil de expressão espaço-temporal determinado para o gene Hipk2 durante o desenvolvimento de camundongos. De maneira geral, a expressão é observada em níveis ubíquos a partir do $9.5 \mathrm{dpc}$. A expressão do gene passa a ser maior em tecidos nervosos a partir de $11.5 \mathrm{dpc}$, e se estende até a última fase do desenvolvimento analisada, em embriões com $17.5 \mathrm{dpc}$. Outros órgãos como fígado e rim também são locais de expressão de Hipk2, mas nestes o transcrito foi observado em estágios mais tardios.

Os resultados observados discordam daqueles de Pierantoni e colaboradores (2002), que pela mesma técnica observaram a expressão do gene somente a partir do $15.5 \mathrm{dpc}$. Neste trabalho foi identificada a expressão ampla a partir do 9.5dpc. Mais recentemente, Isono e colaboradores (2006) avaliaram a expressão de Hipk2 especificamente no $9.5 \mathrm{dpc}$, e concluíram também que o transcrito era amplamente expresso com maior concentração em tecidos nervosos, na vesícula óptica e na vesícula ótica. 


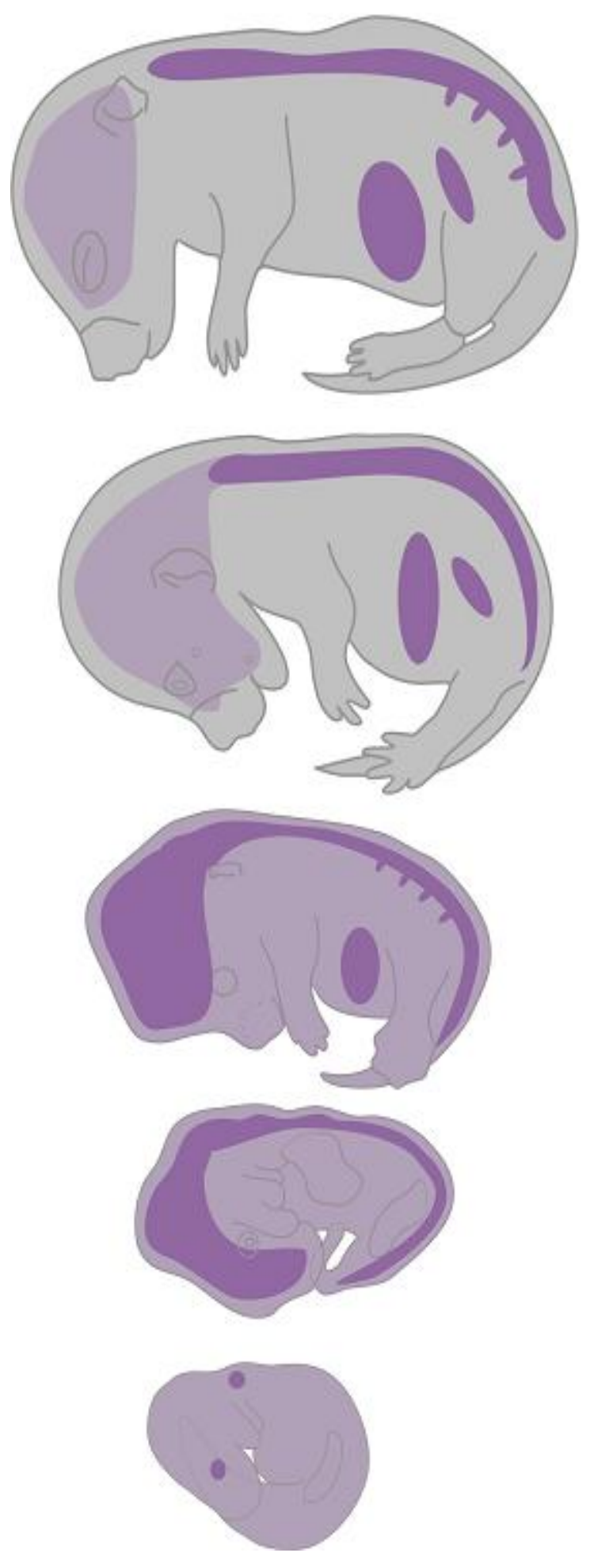

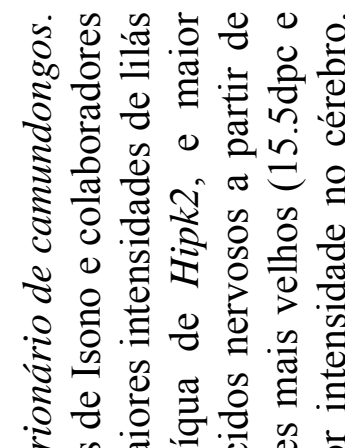
है

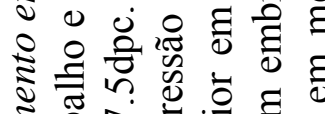

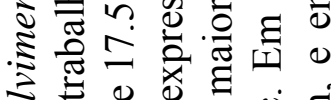

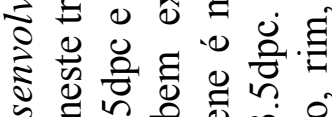

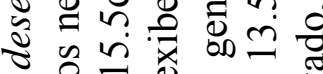
० 윰 0 용

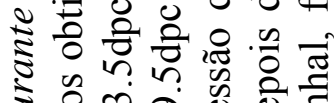
苛

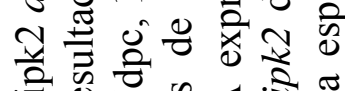

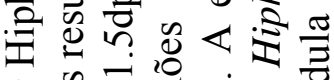
ช

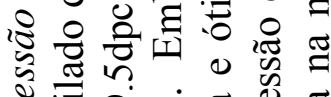
ข

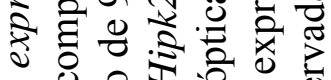

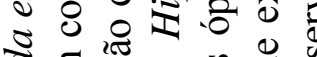

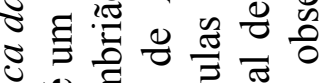
:

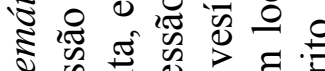

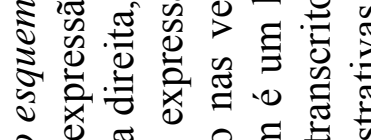

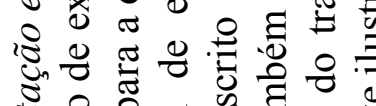

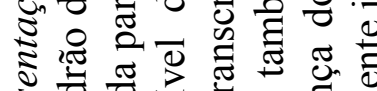

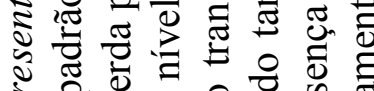
뉸

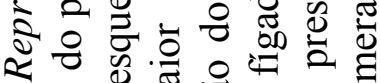

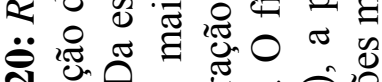

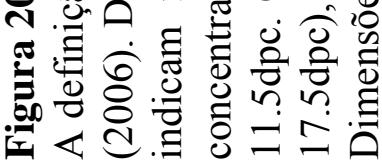


Wiggins e colaboradores (2004) verificaram a presença do transcrito de Hipk2 em 12.5dpc, em gânglios sensores (trigeminal e vestibulococlear), em gânglios da raiz dorsal e no fígado. Os resultados deste trabalho mostram que, nesta fase do desenvolvimento, o gene é amplamente expresso, mas o transcrito é principalmente observado no cérebro, em gânglios nervosos da raiz dorsal, e em dutos mesonéfricos renais.

Os resultados aqui apresentados de maior expressão de Hipk2 em tecidos nervosos (Fig. 20) sugerem o possível envolvimento do gene durante o desenvolvimento destes. De fato, recentemente foram detectadas anormalidades psicomotoras, causadas por perda de neurônios dopaminérgicos do mesencéfalo por apoptose em animais Hipk2 ${ }^{-/-}$(ZHANG et al., 2007). Sabe-se que TGF $\beta$ é um importante fator neurotrófico para a sobrevivência deste grupo de neurônios durante o 13.5 - 14.5dpc (FARKAS et al., 2003), e que a perda deste fator causa alterações neuronais similares àquelas observadas em mutantes Hipk2 $2^{-/-}$ Assim, os autores concluíram que Hipk2 é um co-fator indispensável da via de sinalização mediada por TGF $\beta$ em neurônios dopaminérgicos.

Observou-se intensa expressão de Hipk2 em gânglios nervosos durante a embriogênese do camundongo, especificamente nos gânglios da raiz dorsal (a partir do 12.5dpc), nos gânglios trigeminais e vestibulococleares (embriões de 14,5dpc). Doxakis e colaboradores (2004) documentaram que Hipk2 possui um pico de expressão em gânglios no estágio que antecede a fase de apoptose normal destes. Além disso, a superexpressão de Hipk2 em cultura de neurônios sensoriais e simpáticos induz morte celular, indicando um papel importante do gene na via de apoptose nestas células.

Em camundongos, neurônios do córtex cerebral são gerados entre $10.5 \mathrm{dpc}$ e $17.5 \mathrm{dpc}$, por um processo proliferativo na zona ventricular do cérebro (MANUEL et al., 2007). Nessa região, foi observada expressão mais pronunciada de Hipk2, sugerindo uma participação do gene na regulação destes eventos de proliferação celular. Estes resultados 
corroboram a conclusão de Zhang (2007), que dependendo do contexto celular, Hipk2 pode induzir morte celular ou agir como fator de sobrevivência.

A expressão de Hipk2 em tecidos nervosos ainda sugere sua participação na padronização do sistema nervoso central. Sabendo que as homeoproteínas da família NK são amplamente expressas em tecidos nervosos, e essenciais durante a diferenciação regional específica de áreas do cérebro (VOLLMER \& CLERC, 1998), pode-se inferir que em camundongo Hipk2 atue também como co-fator destas homeoproteínas, como já foi relatado em drosófila (KIM et al., 1998; CHOI et al., 1999).

Nesse sentido, Isono e colaboradores (2006) propuseram que as proteínas Hipks podem estar envolvidas na integração dos sinais de Sonic hedgehog (Shh) e Bone Morphogenetic Proteins (BMPs), morfógenos que participam da determinação de identidades celulares ao longo do eixo dorso-ventral do tubo neural (BRISCOE et al., 2000; revisto por CHIzHIKOV \& MiLlen, 2005). Camundongos duplo-knockouts Hipk1/Hipk2 exibiram mudanças no padrão de expressão de genes Pax, alvos de Shh e BMP. Outros trabalhos confirmam a associação de Hipks a esses fatores (AKIMARU et al., 1997; DAI et al., 1999; HARADA et al., 2003).

Isono e colaboradores (2006) observaram que o gene é expresso na vesícula óptica e ótica de embriões de $9.5 \mathrm{dpc}$. Neste trabalho também foi observada expressão de Hipk2 no olho em desenvolvimento, em embriões de 14,5dpc. Em conjunto, estes resultados apontam para uma função de Hipk2 durante a morfogênese do olho em camundongos. De fato, Choi e colaboradores (2005) documentaram a função de DHIPK2 (ortólogo de HIPK2 em drosófila) na morfogênese do olho de drosófila. Neste trabalho, a superexpressão de DHIPK2 levou à formação de olhos ectópicos, e a proteína também foi capaz de fosforilar eyeless, uma proteína de fundamental importância na morfogênese do olho (revisto por CHI \& EPSTEIN, 2002). 
Finalmente, alguns órgãos como rins e coração exibem expressão de Hipk2 somente nos estágios finais do desenvolvimento, após o $15^{\circ}$ dia de gestação. Como Hipk2 pode interagir com várias proteínas importantes não só na regulação do ciclo celular como em eventos morfogenéticos, a presença do transcrito do gene neste tecidos pode indicar desde a manutenção de fenótipos já diferenciados como controle de morte celular programada. Novos estudos ajudarão no reconhecimento de funções de Hipk2 em outros tecidos além do nervoso.

\subsection{Regulação de expressão gênica por HIPK2}

Estudos de função gênica em mamíferos fazem uso de diferentes estratégias de silenciamento gênico, incluindo a recombinação homóloga, ribozimas e RNA anti-senso (KHAN et al., 2004; revisto por HuPPI et al., 2005). Mais recentemente, o processo de interferência por RNA (RNAi), inicialmente descrito em Caenorhabditis elegans (FIRE et al., 1998), tornou-se uma poderosa ferramenta de silenciamento gênico utilizada para estudo de função gênica in vitro (revisto por HANNON, 2002).

Foram testados três shRNAs para o silenciamento de HIPK2, dois identificados por programas disponíveis na rede, e um já descrito (Di STEFANO et al., 2004). No entanto, os métodos de predição de siRNAs não são perfeitos, uma vez que cada RNA forma estruturas secundárias e terciárias próprias não completamente previstas por estes métodos, e que podem dificultar seu acesso à maquinaria de silenciamento (revisto por MCMANUS \& ShARP, 2002). Assim, cada alvo deve ser testado empiricamente. Além disso, optou-se pela estratégia de expressão dos shRNAs dentro das células por transfecção estável para se 
evitar a expressão transiente dos shRNAs, o que impediria experimentos de média duração.

A validação dos alvos nas células 293 mostrou um melhor desempenho da construção pS4, que chegou a inibir em até $90 \%$ a expressão de HIPK2. Este valor é muito alto se comparado aos $20 \%$ obtidos em células RKO (linhagem de câncer de cólon humano), o que foi suficiente para se observar conseqüências fenotípicas naquelas células (Di STEFANO et al., 2004).

\subsubsection{Regulação de expressão de HIPK1 e HIPK3 por HIPK2}

O efeito da inibição de HIPK2 na expressão de outros genes foi averiguada nas células transfectadas com pS4. Inicialmente foi investigada a possibilidade de haver efeito compensatório da diminuição de HIPK2 pelos outros genes da família HIPK. As três proteínas HIPKs são muito conservadas e possuem mais de $90 \%$ de homologia no domínio quinase, o que sugere redundância funcional entre elas (CALZADO et al., 2007). De fato, pelo menos duas linhas de evidência indicam redundância funcional entre Hipk2 e Hipk1. Isono e colaboradores (2006) viram que Hipk1 e Hipk2 eram co-expressos amplamente em embriões de camundongos $(9.5 \mathrm{dpc})$, enquanto que Hipk3 exibia um padrão de expressão diferente, mais concentrado em tecidos cardíacos. Além disso, camundongos knockouts para Hipk1 ou Hipk2 são normais (KoNDO et al., 2003; WIGGINS et al., 2004), enquanto que os duplo-knockouts morrem entre o $9^{\circ}$ e o $12^{\circ}$ dia de gestação (IsONO et al., 2006).

As células humanas deficientes em HIPK2 foram testadas quanto à expressão de HIPK1 e HIPK3. A análise por RT-PCR em tempo real mostrou que houve aumento considerável na expressão de HIPK1 (em média 114\%) após silenciamento de HIPK2, 
sugerindo haver de fato um mecanismo de compensação, que provoca o aumento da transcrição daquele gene nas células com níveis de HIPK2 diminuídos. Estes resultados indicam que, além da redundância funcional, existe um mecanismo de controle transcricional de HIPK1 dependente de dosagem de HIPK2, possivelmente levando a uma compensação da diminuição desta última. Este efeito poderia ser investigado in vivo nos animais knockout para Hipk1 e Hipk2.

É importante ressaltar que HIPK3 também teve seus níveis aumentados (em média 43\%) em células com inibição de HIPK2. Alguns trabalhos demonstram que HIPK3 é uma proteína envolvida com indução de apoptose (ROCHAT-STEINER et al., 2000; CURTIN \& COTTER, 2004), o que também sugere sobreposição funcional entre HIPK2 e HIPK3. Novos trabalhos poderão confirmar se existe redundância parcial ou total de função entre HIPK2 e HIPK3, e se também existe um mecanismo dose-dependente de regulação dos níveis de genes HIPKs.

Famílias de genes que apresentam funções compensatórias são comuns em mamíferos (KONG et al., 2007) como, por exemplo, os oito genes da família de proteínas E2F, importantes reguladoras da transcrição durante o ciclo celular (revisto por DIMOVA \& DYSON, 2005). Em camundongos, a deleção de genes E2F isolados não é suficiente para impedir a entrada na fase $\mathrm{S}$ celular, mas a perda combinada das proteínas bloqueia a mudança de fase (HUMBERT et al., 2000; Wu et al., 2001). Além da redundância funcional, Kong e colaboradores (2007) verificaram que existe também uma compensação de níveis de E2F3 em fibroblastos murinos provenientes de camundongos knockout para E2F1, e vice-versa, sugerindo um mecanismo dose-dependente de controle da transcrição destes genes, como foi observado neste trabalho com relação aos genes HIPKs. 


\subsubsection{Controle da expressão de genes homeobox por HIPK2.}

Entre as diferentes funções já descritas para Hipk2 em modelos animais, seu papel durante a embriogênese e no controle de expressão gênica é de especial interesse. Uma vez que a proteína foi identificada por sua associação com as homeoproteínas da classe NK em modelos animais (KIM et al. 1998), suspeita-se que ela possa desempenhar funções semelhantes em células humanas. Assim, foi analisado o efeito do silenciamento de HIPK2 na expressão daqueles genes homeobox.

Não foram observadas alterações significativas nos níveis de transcrição do gene NKX2.5 nas células deficientes para HIPK2. Entretanto, não se pode excluir que HIPK2 controle a atividade desta proteína por outro mecanismo. Em camundongos, não foi investigado se Hipk2 fosforila Nkx2.5 (KIM et al., 1998), mas viu-se que essas duas proteínas interagem. A fosforilação pode causar mudanças na estabilidade deste fator de transcrição, na capacidade deste se ligar ao DNA, na sua localização subcelular ou na sua capacidade de interagir com outras proteínas. Nesse sentido, seria importante analisar modificações na proteína NKX2.5, assim como ampliar a análise de níveis de expressão para genes regulados diretamente por NKX2.5 nas células interferidas.

NKX3.1 apresentou aumento de expressão (em média 85\%) nas células interferidas. A proteína NKX3.1 é o possível ortólogo de NK3 de drosófila. Como já mencionado, Kim e colaboradores (1998) descreveram a participação de Hipk2 no controle da transcrição mediada por NK3. Os autores verificaram que NK3 realiza repressão do seu próprio promotor (feedback negativo) e o aumento de expressão de Hipk2 potencializa o efeito auto-repressor de NK3. O aumento de expressão de NKX3.1 nas células deficientes para HIPK2 aqui identificado sugere que HIPK2 humana regule negativamente a expressão de NKX3.1, como em drosófila. 
A região 8p21, onde se localiza $N K X 3.1$ humano, sofre perda de heterozigose em cerca de $85 \%$ dos casos de câncer de próstata (VOCKE et al., 1996). No entanto, não foram encontradas mutações na região codificadora de $N K X 3.1$ em tecidos de câncer de próstata humanos (Voeller et al., 1997). Contudo, a alta freqüência de perda de NKX3.1 em tumores humanos, a diminuição de expressão com a progressão tumoral e a existência de modelos animais que demonstram haploinsuficiência dominante de $N k x 3.1$ indicam que o gene tem papel decisivo no câncer da próstata (revisto por GELMANN, 2003). Evidências que confirmem a regulação de NKX3.1 por HIPK2 podem apontar para um envolvimento desta última na carcinogênese da próstata.

Os resultados das hibridações in situ revelaram que Hipk2 é expresso no tubo neural e no olho durante o desenvolvimento. Por este motivo, genes que também são expressos nestes tecidos foram avaliados nas células humanas onde HIPK2 foi inibido. Nkx6.1 e Pax6 são genes homeobox expressos no tubo neural em desenvolvimento, onde possuem fundamental importância na determinação de subtipos neuronais (BRISCOE et al., 2000; revisto por ChizhiKov \& MiLlen, 2005). Neste tecido, eles são transcritos em resposta a um gradiente dorso-ventral de sinalização de Shh (BRISCOE et al., 2000).

Além disso, Pax6 é o ortólogo de eyeless de drosófila em camundongos (QUIRING et al., 1994; revisto por GeHRING \& IKEO, 1999; revisto por CHI \& EPSTEIN, 2002). Mutação no gene Pax6 em homozigose provoca ausência de olhos e de cavidades nasais, e morte neonatal (HOGAN et al., 1986; revisto por GEHRING \& IKEO, 1999). Em humanos, mutações em heterozigose em PAX6 causam aniridia, uma malformação congênita caracterizada por perda quase total da íris (TON et al., 1991; HANSON \& VAN HEYNINGEN, 1995).

A expressão de Hipk2, uma proteína que interage com homeoproteínas, no olho em desenvolvimento sugere que esta pode interagir com Pax6. Esta hipótese foi testada em 
células humanas, onde foi verificada se a expressão de PAX6 humano é alterada nas células deficientes em HIPK2. Tanto PAX6 quanto NKX6.1 apresentaram aumento no nível dos seus transcritos (em média 29\% e 44\%, respectivamente) nas células humanas onde ocorreu inativação de HIPK2. Este resultado indica que HIPK2 regula negativamente a expressão destes genes.

De fato, recentemente Kim e colaboradores (2006) observaram que Hipk2 interage e é capaz de fosforilar Pax6 murina, confirmando a hipótese levantada pelos resultados das hibridações in situ. Como já relatado, DHIPK2 fosforila eyeless em drosófila. Assim, a associação de DHIPK2/eyeless e Hipk2/Pax6 indica que esta regulação é conservada entre drosófila e mamíferos. Os resultados deste trabalham mostram que HIPK2 modula a atividade de PAX6 também no nível da transcrição.

O efeito da fosforilação de Pax6 por Hipk2 foi avaliado por Kim e colaboradores (2006) utilizando a região promotora do gene de proglucagon, responsiva a Pax6. Assim, os autores propuseram que outras homeoproteínas envolvidas na homeostase de glicose também poderiam ser alvo de Hipk2. Nkx6.1 além de ser expresso em células nervosas, é expresso no pâncreas em desenvolvimento, e sua inativação em camundongos resulta em perda quase total de células-beta, produtoras de insulina (SANDER et al., 2000). Como PAX6, nas células humanas deficientes em HIPK2, NKX6.1 também teve aumento de expressão. O aumento de expressão de dois genes envolvidos na homeostase de glicose em conseqüência do silenciamento de HIPK2 corroboram a hipótese de que este último pode estar envolvido nesta via.

É importante ressaltar que não foram avaliados os estados fosforilados das homeoproteínas aqui testadas. Para uma melhor compreensão do efeito molecular do silenciamento de HIPK2, ensaios de Western-blot com anticorpos que reconhecem as formas fosforiladas das proteínas deveriam ser realizados. Além disso, análises mais 
amplas de expressão gênica (array de expressão) e proteômica nas células deficientes em HIPK2 poderão identificar outras vias de atuação deste gene. 
Este trabalho apresenta uma análise do padrão de expressão temporal e espacial de Hipk2 durante o desenvolvimento embrionário a partir do início da organogênese, de 9.5dpc até 17.5dpc. Esta análise revelou um possível papel de Hipk2 no início da organogênese, fase na qual o gene é expresso em todos os tecidos do embrião. Além disso, a concentração dos transcritos de Hipk2 em tecidos neurais a partir do 11.5 dpc até estágios mais tardios do desenvolvimento sugerem a participação da proteína na morfogênese destes tecidos. De fato, recentemente foram identificados fenótipos neurais em camundongos knockout para Hipk2 (ZHANG et al., 2007). A determinação do padrão de expressão de Hipk2 poderá orientar novas investigações sobre sua função nos diferentes órgãos durante o desenvolvimento embrionário.

A segunda parte deste trabalho teve por objetivo estabelecer um modelo experimental de análise de função de HIPK2 em células humanas. Utilizando a técnica de interferência por RNA (RNAi), pôde-se inativar HIPK2 humano, e avaliar os efeitos desta inibição sobre a expressão de outros genes.

O aumento de expressão de genes HIPKs nas células interferidas sugere que, além de existir redundância funcional entre as proteínas HIPKs, como propõem alguns trabalhos (ISONO et al., 2006; CALZADO et al., 2007), deve haver um mecanismo compensatório dose-dependente de controle de expressão de genes HIPKs. Isto por sua vez abre novas perspectivas de estudo de regulação desta família gênica.

Além disso, o aumento de expressão dos genes NKX3.1, NKX6.1 e PAX6 nas células interferidas indica que HIPK2 pode agir como repressor transcricional de genes homeobox em humanos. No entanto, como HIPK2 não é um fator de transcrição, é mais provável que sua atuação seja indireta, o que deverá ser avaliado por estudos de proteínas. Finalmente, as células deficientes para HIPK2 servem como um sistema experimental in 
vitro onde poderão ser identificadas as diferentes vias de atuação desta proteína em humanos. 


\section{REFERÊNCIAS BIBLIOGRÁFICAS}

Akimaru H, Chen Y, Dai P, Hou DX, Nonaka M, Smolik SM, Armstrong S, Goodman RH, ISHII S. Drosophila CBP is a co-activator of cubitus interruptus in hedgehog signalling. Nature, 1997; 386: 735-8.

AZPIAZU N, FRASCH M. tinman and bagpipe: two homeo box genes that determine cell fates in the dorsal mesoderm of Drosophila. Genes Dev., 1993; 7(7B): 1325-40.

BATESON W. Materials for the study of variation. New York, Macmillan, 1894.

Benson DW, Silberbach GM, Kavanaugh-McHugh A. Mutations in de cardiac transcription factor NKX2.5 affect diverse cardiac developmental pathways. J. Clin. Invest., 1999; 104: 1567-73.

BILleter M. Homeodomain-type DNA recognition. Prog. Biophys. Mol. Biol., 1996; 66(3): 211-25.

Brennan RG, Matthews BW. The helix-turn-helix DNA binding motif. J. Biol. Chem., 1989; 264(4): 1903-6.

Briscoe J, Pierani A, Jessel TM, Ericson J. A homeodomain protein code specifies progenitor cell identity and neuronal fate in the ventral neural tube. Cell, 2000;101(4): $435-45$. 
Brummelkamp TR, Bernards R, Agami R. A system for stable expression of short interfering RNAs in mammalian cells. Science, 2002; 296:550-3.

Calzado MA, Renner F, Roscic A, Schmitz ML. HIPK2: a versatile switchboard regulating the transcription machinery and cell death. Cell Cycle., 2007; 6(2):139-43.

CAMARgo AA et al. The contribution of 700,000 ORF sequence tags to the definition of the human transcriptome. Proc. Natl. Acad. Sci. U.S.A., 2001; 98(21):12103-8.

Chi N, Epstein JA. Getting your Pax straight: Pax proteins in development and disease. Trends Genet., 2002; 18(1): 41-7.

ChizhiKov VV, MiLlen KJ. Roof plate-dependent patterning of the vertebrate dorsal central nervous system. Dev. Biol., 2005; 277(2): 287-95.

CHOI CY, KIm YH, KwON HJ, KIM Y. The homeodomain protein NK-3 recruits Groucho and a histone deacetylase complex to repress transcription. J. Biol. Chem., 1999; 274(47): 33194-7.

Choi CY, Kim YH, Kim YO, PARK SJ, Kim EA, Riemenschneider W, GAJEWSKi K, SCHULZ RA, KIM Y. Phosphorylation by the DHIPK2 protein kinase modulates the corepressor activity of Groucho. J. Biol. Chem., 2005; 280(22): 21427-36. 
CURTIN JF, COTTER TG. JNK regulates HIPK3 expression and promotes resistance to Fasmediated apoptosis in DU 145 prostate carcinoma cells. J. Biol. Chem., 2004; 279(17): 17090-100.

D'Orazi G, Cecchinelli B, Bruno T, Manni I, Higashimoto Y, Saito S, Gostissa M, Coen S, Marchetti A, Del Sal G, Piaggio G, Fanciulli M, Appella E, Soddu S. Homeodomain-interacting protein kinase-2 phosphorilates p53 at Ser 46 and mediates apoptosis. Nat. Cell. Biol., 2002; 4(1):11-9.

Dai P, Akimaru H, Tanaka Y, Maekawa T, Nakafuku M, Ishit S. Sonic Hedgehoginduced activation of the Gli1 promoter is mediated by GLI3. J. Biol. Chem., 1999; 274: $8143-52$

Dauth I, Kruger J, Hofman TG. Homeodomain-interacting protein kinase 2 is the ionizing radiation-activated p53 serine 46 kinase and is regulated by ATM. Cancer Res., 2007; 67(5): 2274-9.

DiAs NETO E et al. Shotgun sequencing of the human transcriptome with ORF expressed sequence tags. Proc. Natl. Acad. Sci. U.S.A., 2000; 97(7): 3491-6.

Dimova DK, DYson NJ. The E2F transcriptional network: old acquaintances with new faces. Oncogene. 2005; 24(17): 2810-26. 
Di Stefano V, Rinaldo C, Sacchi A, Soddu S, D’Orazi G. Homeodomain-interacting protein kinase- 2 activity and p53 phosphorylation are critical events for cisplatin -mediated apoptosis. Exp. Cell. Res., 2004; 293: 311-320.

Doxakis E, HuANG EJ, DAVIES AM. Homeodomain-interating protein kinase-2 regulates apoptosis in developing sensory and sympathetic neurons. Curr. Biol., 2004; 14: 1761-5.

Duboule D. The vertebrate limb: a model system to study the Hox/HOM gene network during development and evolution. Bioessays, 1992; 14(6): 375-84.

Farkas LM, Dunker N, Roussa E, Unsicker K, KRIEGLSTEIn K. Transforming growth factor-beta(s) are essential for the development of midbrain dopaminergic neurons in vitro and in vivo. J. Neurosci., 2003; 23: 5178-86.

Favier B, Dollé P. Developmental functions of mammalian Hox genes. Mol. Hum. Reprod.,1997; 3: 115-131.

Fire A, Xu SQ, Montgomery MK, Kostas SA, Driver SE, Mello CC. Potent and specific genetic interference by double-stranded RNA in Caenorhabditis elegans. Nature, 1998; 391: 806-10.

GEHRING WJ. Homeo boxes in the study of development. Science, 1987; 236 (4806): 124552. 
Gehring WJ, IKeO K. Pax 6: mastering eye morphogenesis and eye evolution. Trends Genet., 1999; 15(9): 371-7.

GELMANN EP. Searching for the gatekeeper oncogene of prostate cancer. Crit. Rev. Oncol. Hematol., 2003;46 Suppl: S11-20.

HANNON GJ. RNA interference. Nature, 2002; 418(6894): 244-51.

Hanson I, Van Heyningen V. Pax6: more than meets the eye. Trends Genet.,1995; 11(7): 268-72.

Harada J, Kokura K, Kanei-Ishit C, Nomura T, M. Khan MM, Kim Y, Ishit S. Requirement of the co-repressor homeodomain-interacting protein kinase 2 for skimediated inhibition of bone morphogenetic protein-induced transcriptional activation. $J$. Biol. Chem., 2003; 278: 38998-9005.

HARVEY RP. NK-2 homeobox genes and heart development. Dev. Biol., 1996; 178(2): 203-16.

Hochgreb T, Linhares VL, Menezes DC, Sampaio AC, Yan CY, Cardoso WV, Rosenthal N, XAVIER-Neto J. A caudorostral wave of RALDH2 conveys anteroposterior information to the cardiac field. Development, 2003; 130(22): 5363-74. 
Hofmann TG, Mincheva A, Lichter P, Droge W, Schmitz ML. Human homeodomaininteracting protein kinase-2 (HIPK2) is a member of the DYRK family of protein kinases and maps to chromosome 7q32-q34. Biochimie., 2000; 82(12):1123-7.

Hogan BLm, Horsburgh G, Cohen J, Hetherington CM, Fisher G, Lyon MF. Small eyes (Sey): a homozygous lethal mutation on chromosome 2 which affects the differentiation of both lens and nasal placodes in the mouse. J. Embryol. Exp. Morphol., 1986; 97: 95-110.

Humbert PO, Verona R, trimarchu JM, Rogers C, DANDAPAni S, Lees JA. E2f3 is critical for normal cellular proliferation. Genes Dev., 2000;14(6):690-703.

Huppi K, Martin SE, CAPLen NJ. Defining and assaying RNAi in mammalian cells. Mol. Cell, 2005; 17(1): 1-10.

Isono K, Nemoto K, Li Y, YAKada Y, SUZUKi R, KATsumi M, NAKAgawara A, Koseki H. Overlapping roles for homeodomain-interacting protein kinases hipk1 and hipk2 in the mediation of cell growth in response to morphogenetic and genotoxic signals. Mol. Cell. Biol., 2006; 26(7): 2758-71.

KAPPEN C, SCHUGHART K, RUDDLE FH. Early evolutionary origin of major homeodomain sequence classes. Genomics, 1993; 18: 54-70.

KARIN M, HUNTER T. Transcriptional control by protein phosphorylation: signal transmission from the cell surface to the nucleus. Curr. Biol., 1995; 5(7): 747-57. 
Kaufman MH. Atlas of mouse development. First Edition, San Diego, USA: Academic Press; 1992.

Kaufman TC, Lewis R, Wakimoto B. Cytogenetic Analysis of Chromosome 3 in Drosophila melanogaster: The Homoeotic Gene Complex in Polytene Chromosome Interval 84a-B. Genetics, 1980; 94(1): 115-33.

Khan A, Benboubetra M, Sayyed PZ, Ng KW, Fox S, Beck G, Benter IF, Akhtar S. Sustained polymeric delivery of gene silencing antisense ODNs, siRNA, DNAzymes and ribozymes: in vitro and in vivo studies. J. Drug Target, 2004; 12(6): 393-404.

Kim EA, Noh YT, Ryu MJ, Kim HT, Lee SE, Kim CH, Lee C, Kim YH, Choi CY. Phosphorylation and transactivation of Pax6 by homeodomain-interacting protein kinase 2 . J. Biol. Chem., 2006; 281(11): 7489-97.

Kim Y, Nirenberg M. Drosophila NK-homeobox genes. Proc. Natl. Acad. Sci. U. S. A., 1989; 86(20): 7716-20.

KIM YH, CHOI CY, LEE SJ, CONTI MA, KIM Y. Homeodomain-interacting protein kinases, a novel family of co-repressors for homeodomain transcription factors. J. Biol. Chem., $1998 ; 273: 25875-9$.

De KoK JB, Roelofs RW, Giesendorf BA, Pennings JL, WaAs ET, Feuth T, Swinkels DW, SPAN PN. Normalization of gene expression measurements in tumor tissues: comparison of 13 endogenous control genes. Lab. Invest., 2005; 85(1):154-9. 
Komuro I, Izumo S. Csx: A murine homiobox-containing gene specifically expressed in the developing heart. Proc. Natl. Acad. Sci. U.S.A., 1993; 90: 8145-9.

Kondo S, Lu Y, Debbas M, Lin AW, Sarosi i, Itie A, Wakeham A, Tuan J, Saris C, Elliott G, Ma W, Benchimol S, Lowe SW, MAK TW, Thukral SK. Characterization of cells and gene-targeted mice deficient for the p53-binding kinase homeodomaininteracting protein kinase 1 (HIPK1). Proc. Natl. Acad. Sci. U.S.A., 2003; 100(9): 5431-6.

Kong L-J, Chang JT, Bild AH, Nevins JR. Compensation and specificity of function within the E2F family. Oncogene, 2007; 26: 321-327.

LANDER ES et al. Initial sequencing and analysis of the human genome. Nature, 2001; 409: $860-921$.

LEWIS EB. A gene complex controlling segmentation in Drosophila. Nature,1978; 276(5688): 565-70.

Li X, WANG Y, Debatin KN, Hug H. The serine/threonine kinase HIPK2 interacts with TRADD, but not with CD95 or TNF-R1 in 293 T cells. Biochem. Biophys. Res. Commun., $2000 ; 277(2): 513-7$.

Lints TJ, Parsons LM, Hartley L, Lyons I, Harvey RP. $N k x-2.5$ : a novel murine homeobox gene expressed in early heart progenitor cells and their myogenic descendants. Development, 1993; 119: 419-431. 
Lyons i, Parsons lm, Hartley L, R. Li R, Andrews Je, Robb L, Harvey RP. Myogenic and morphogenetic defects in the heart tubes of murine embryos lacking the homeo box gene Nkx2-5. Genes \& Devel., 1995; 9: 1654-66.

Manuel M, Georgala PA, Carr CB, Chanas S, Kleinjan DA, Martynoga B, Mason JO, Molinek M, PinsonJ, Pratt T, Quinn JC, Simpson TI, Tyas DA, VAn Heyningen V, WeSt JD, PRICE DJ. Controlled overexpression of Pax6 in vivo negatively autoregulates the Pax6 locus, causing cell-autonomous defects of late cortical progenitor proliferation with little effect on cortical arealization. Development, 2007;134(3): 545-55.

MCGinNis W, Krumlauf R. Homeobox genes and axial patterning. Cell, 1992; 68(2): 283-302.

McGinnis W, Levine MS, Hafen E, Kuroiwa A, GeHring WJ. A conserved DNA sequence in homoeotic genes of the Drosophila Antennapedia and bithorax complexes. Nature, 1984; 308: 428-33.

MCMANUS MT, SHARP, PA. Gene silencing in mammals by small interfering RNAs. Nat. Rev. Genet., 2002; 3(10): 737-47.

Naito Y, Yamada T, Ui-Tei K, Morishita S, SAigo K. siDirect: highly effective, targetspecific siRNA design software for mammalian RNA interference. Nucleic Acids Res., 2004; 32 (web Server issue):W124-9. 
Oda K, Arakawa H, Tanaka T, Matsuda K, Tanikawa C, Mori T, Nishimori H, TAMAI K, TOKINO T, NAKAmURA Y, TAYA Y. p53AIP1, a potential mediator of p53dependent apoptosis, and its regulation by Ser-46-phosphorylated p53. Cell, 2000; 102(6): $849-62$.

Okamura S, Arakawa H, Tanaka T, Nakanishi H, Ng CC, Taya Y, Monden M, NAKAMURA Y. p53DINP1, a p53-inducible gene, regulates p53-dependent apoptosis. Mol. Cell, 2001; 8(1): 85-94.

Patterson KD, Cleaver o, Gerber WV, Grow mW, Newman CS, Krieg PA. Homeobox genes in cardiovascular development. Curr. Top. Dev. Biol., 1998; 40:1-44.

Pierantoni GM, Bulfone A, Pentimalli F, Fedele M, Iuliano R, Santoro M, Chiariotti L, BALlabio A, Fusco A. The homeodomain-interactin protein kinase 2 gene is expressed late in the embryogenesis and preferentially in retina, muscle, and neural tissues. Biochem. Biophys. Res. Commun., 2002; 290 (3): 942-7.

Qian YQ, Billeter M, Otting G, Müller M, Gehring, WJ, WÜthrich K. The structure of the Antennapedia homeodomain determined by NMR spectroscopy in solution: comparison with prokaryotic repressors. Cell, 1989; 59(3): 573-80.

Quiring R, Walldorf U, Kloter U, Gehring WJ. Homology of the eyeless gene of Drosophila to the Small eye gene in mice and Aniridia in humans. Science, 1994; 265(5173): 785-9. 
Rochat-Steiner V, Becker K, Micheau O, Schneider P, Burns K, Tschopp J. FIST/HIPK3: a Fas/FADD-interacting serine/threonine kinase that induces FADD phosphorylation and inhibits fas-mediated Jun NH(2)-terminal kinase activation. J. Exp. Med. 2000; 192(8): 1165-74.

Rogers S, Wells R, ReCHSTEINER M. Amino acid sequences common to rapidly degraded proteins: the PEST hypothesis. Science, 1986; 234:364-8.

Sander M, Sussel L, Conners J, Scheel D, Kalamaras J, Dela Cruz F, Schwitzgebel V, Hayes-Jordan A, German M. Homeobox gene Nkx6.1 lies downstream of Nkx2.2 in the major pathway of beta-cell formation in the pancreas. Development, 2000; 127(24): 5533-40.

Schott JJ, Benson DW, Basson CT, Pease W, Silberbach GM, Moak JP, Maron BJ, Seidman CE, SeIDMAn JG. Congenital heart disease caused by mutations in the transcription factor NKX2-5. Science, 1998; 281(5373):108-11.

SCOTT MP, WeINER AJ. Structural relationships among genes that control development: Sequence homology between Anthennapedia, Ultrabithorax, and fushi tarazu loci of Drosophila. Proc. Natl. Acad. Sci. U.S.A., 1984; 81: 4115-19.

Stanfel MN, Moses KA, SchWARTZ RJ, ZimMER WE. Regulation of organ development by the NKX-homeodomain factors: an NKX code. Cell. Mol. Biol., 2005; 51: 785-99. 
StUKART GC. Caracterização de HIPK2, um novo gene humano [dissertação]. São Paulo: Fundação Antônio Prudente; 2001.

TON CC et al. Positional cloning and characterization of a paired box- and homeoboxcontaining gene from the aniridia region. Cell, 1991; 67(6): 1059-74.

Vandesompele J, De Preter K, Pattyn F, Poppe B, Van Roy N, De Paepe A, Speleman F. Accurate normalization of real-time quantitative RT-PCR data by geometric averaging of multiple internal control genes. Genome Biol., 2002; 3(7): research 0034.

VENTER JC et al. The sequence of the human genome. Science, 2001; 291: 1304-51.

Vocke CD, Pozzatti RO, Bostwick DG, Florence CD, Jennings SB, Strup SE, Duray PH, LiOTTA LA, EMMERT-Buck MR, LineHAN WM. Analysis of 99 microdissected prostate carcinomas reveals a high frequency of allelic loss on chromosome 8p21-22. Cancer Res., 1996; 56: 2411-6.

Voeller HJ, Augustus M, Madlike V, Bova GS, Carte KC, Gelmann EP. Coding region of NKX3.1, prostate-specific homeobox gene on $8 \mathrm{p} 21$, is not mutated in human prostate cancers. Cancer Res., 1997; 57: 4455-9.

Vollmer J, Clerc RG. Homeobox genes in the developing mouse brain. J. Neurochem., 1998; 71:1-19. 
WALther C, GRuss P. Pax-6, a murine paired box gene, is expressed in the developing CNS. Development, 1991; 113(4): 1435-49.

Wang Y, Debatin K-M, Hug H. HIPK2 overexpression leads to stabilization of p53 protein and increased p53 transcriptional activity by decreasing Mdm2 protein levels. BMC. Mol. Biol., 2001; 2:8.

WANG Y, Schneider EM, Li X, DutTenhöFER I, DebAtin KM, Hug H. HIPK2 associates with RanBPM. Biochem. Biophys. Res. Comm., 2002; 297:148-53.

Wiggins AK, Wei G, Doxakis E, Wong C, Tang AA, Zang K, Luo EJ, Neve RL, REICHARDT LF, HuANG EJ. Interaction of Brn3a and HIPK2 mediates transcriptional repression of sensory neuron survival. J. Cell. Biol., 2004; 167(2): 257-67.

Wu L, Timmers C, Maiti B, SAAvedra Hi, SANG L, Chong GT, Giangrande P, Wright FA, Field SJ, Greenberg ME, ORKin S, Nevins JR, Robinson ML, LEONE G. The E2F13 transcription factors are essential for cellular proliferation. Nature, 2001; 414(6862): $457-62$.

ZAFFRAN S, FRASCH M. The beta3 tubulin gene is a direct target of bagpipe and biniou in the visceral mesoderm of drosophila. Mech. Dev., 2002; 114: 85-93.

Zhang J, Pho V, Bonasera SJ, Holtzman J, TAng AT, Hellmuth J, Tang S, Janak PH, TeCott LH, HuAng EJ. Essential function of HIPK2 in TGFbeta-dependent survival of midbrain dopamine neurons. Nat. Neurosci., 2007; 10(1): 77-86. 
ZHANG X, DING L, SANDFORD AJ. Selection of reference genes for gene expression studies in human neutrophils by real-time PCR. BMC Mol. Biol., 2005; 6(1): 4. 